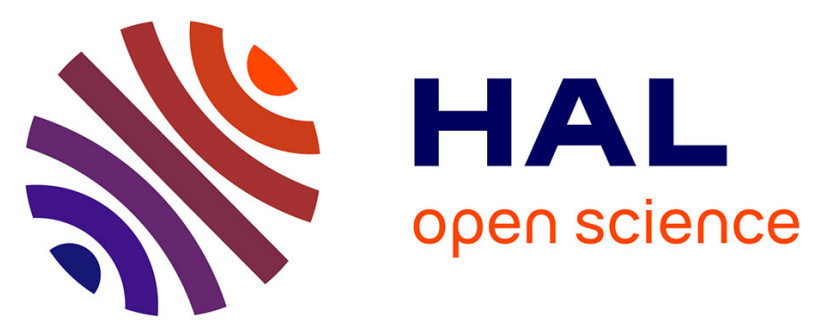

\title{
Scent lineups compared across eleven countries: Looking for the future of a controversial forensic technique
}

\author{
Barbara Ferry, John Ensminger, Adee Schoon, Zbignev Bobrovskij, David \\ Cant, Maciej Gawkowski, Iilkka Hormila, Pavel Kos, Ferenc Less, Elena \\ Rodionova, et al.
}

\section{To cite this version:}

Barbara Ferry, John Ensminger, Adee Schoon, Zbignev Bobrovskij, David Cant, et al.. Scent lineups compared across eleven countries: Looking for the future of a controversial forensic technique. Forensic Science International, 2019, 302, pp.109895. 10.1016/j.forsciint.2019.109895 hal-02395097

\section{HAL Id: hal-02395097 \\ https://hal.science/hal-02395097}

Submitted on 13 Oct 2021

HAL is a multi-disciplinary open access archive for the deposit and dissemination of scientific research documents, whether they are published or not. The documents may come from teaching and research institutions in France or abroad, or from public or private research centers.
L'archive ouverte pluridisciplinaire HAL, est destinée au dépôt et à la diffusion de documents scientifiques de niveau recherche, publiés ou non, émanant des établissements d'enseignement et de recherche français ou étrangers, des laboratoires publics ou privés. 
1 Scent lineups compared across eleven countries: looking for the future of a

2 controversial forensic technique

4 Barbara Ferry ${ }^{\mathrm{a}, \mathrm{b}}$, John J. Ensminger ${ }^{\mathrm{c}}$, Adee Schoon ${ }^{\mathrm{d}}$, Zbignev Bobrovskij ${ }^{\mathrm{e}}$, David Cant, ${ }^{\mathrm{f}}$ Maciej

5 Gawkowski $^{\mathrm{g}}$, IIlkka Hormila ${ }^{\mathrm{h}}$, Pavel Kos ${ }^{\mathrm{i}}$, Ferenc Less ${ }^{\mathrm{j}}$, Elena Rodionovak ${ }^{\mathrm{k}}$, Klim T. Sulimov ${ }^{\mathrm{l}}$, Leif

6 Woidtke $^{\mathrm{m}}$, Tadeusz Jezierski ${ }^{\mathrm{m}}$

7 a. Centre de Recherche en Neurosciences de Lyon, CNRS UMR5292, INSERM U1028, Université Claude

8 Bernard Lyon 1, Université de Lyon, Centre Hospitalier Le Vinatier - Bâtiment 462 - Neurocampus, 95

9 boulevard Pinel, 69675 Bron Cedex, France, barbara.ferry@cnrs.fr

10 b. Forensic Research Group, UQTR, 3351 Boulevard des Forges, Trois-Rivières, QC, Canada

11 c. Delta Hedge Consulting, Rhinebeck, New York, jensminger@msn.com

12 d. Animal Detection Consultancy, Leiden

13 e. Lithuanian Police Forensic Science Centre, Vilnius

14 f. Canine Service of the Belgian Federal Police

15 g . Retired Officer of Police Cynology Department of the Police Training Center, Sulkowice, Poland

16 h. Police Dog Training Centre, Finnish Police University Centre (ret.)

17

18 i. Tuchomerice Dog Regional Group, Odorology Section, Prague

19 j. Education and Training Centre of Hungarian Police Dunakeszi

20 k. Russian Research Institute for Cultural and Natural Heritage, Moscow (ret.)

21 1. Leipzig University, Institute of Legal Medicine, University of Applied Police Sciences Rothenburg

$22 \mathrm{~m}$. Institute of Genetics and Animal Breeding, Polish Academy of Sciences, Jastrzebiec, Poland,

$23 \quad$ t.jezierski@ighz.pl 
A scent lineup is generally a procedure whereby a dog's alerting behavior is used to establish that the dog detects two scents, one from a crime scene and one from a suspect, as being identical. The aim of this article is to compare methodologies of using dogs in scent lineups as a means of identifying perpetrators of crimes. It is hoped that this comparative approach, looking at countries where the method is currently or has in the past been used, will help determine what issues should be addressed in order to assure that the scent lineup will have a future as a forensic technique. Participants from eleven countries-Belgium, The Czech Republic, Finland, France, Germany, Hungary, Lithuania, The Netherlands, Poland, Russia, and the U.S.- completed a survey questionnaire regarding key aspects of the scent lineup procedures used by the police in their countries. Although there was broad overlap on certain matters, such as the use of control and zero trials, collection of decoy scents from individuals of similar gender and race as the suspect, materials for holding scent, frequency of cleaning and changing stations, and use and timing of rewards, there were significant differences in the degree of blindness required, who calls an alert (handler or experimenter), and whether handlers can work with more than one dog. The gap between recommendations and results available from the scientific literature and procedures used in police practice was greater for some countries than others, even taking into account that some scientific methodologies might be expensive or impractical given agency resources. The authors make recommendations about

42 how to go forward if scent lineups are to remain a valid forensic technique.

\section{INTRODUCTION}

45 Trained dogs working in scent lineups have, in many countries, been considered a valid identification 46 method for identifying perpetrators who left their scents at crime scenes (Bednarek 2008; Ensminger

47 2012; Prada et al. 2015). This sort of forensic technique (sometimes denominated osmology or 48 odorology) remains controversial despite its usefulness. The results of such identifications were 49 sometimes introduced as evidence in criminal courts as the primary or even the only evidence, although 50 many judges insist that scent evidence must be corroborative. Initially, testimony given by dog handlers 
51 was, and in some countries still may be, accepted in courts as sufficient proof of the reliability of this

52 identification method (Gerritsen \& Haak 2010).

53

54 Many of the programs were initially created by police authorities, which implemented procedures and 55 rules derived from practical experience of handlers working with dogs (Kaldenbach 1998; Bednarek

56 2008). Courts, however, began raising questions as to the reliability of a methodology based on practical

57 experience, and scent lineup procedures became a subject of scientific inquiry, particularly beginning in

58 the 1990s (Schoon \& De Bruin 1994; Schoon 1996 and 1998; Jezierski et al. 2008; Marchal et al. 2016).

59

60 A positive attitude of law enforcement officials to the lineup procedure, and a need for a practical

61 identification method that could be implemented with quality controls, led to the creation of police units

62 with dedicated staff and specially trained dogs, often centralized for a country or a region of a country.

63 Unfortunately, handlers performing scent lineups have sometimes made excessive claims as to the

64 perfection of their dogs despite a sparsity of studies conducted with scientific scrutiny to support such an

65 optimistic view of the reliability of this method (Taslitz 1990; Ensminger 2012). Therefore, the technique

66 has sometimes been attacked as "junk science" and the quality of the evidence produced by the technique

67 has been called into question by lawyers, judges, and the press (Thomas 2015). Prosecutions have

68 sometimes resulted in acquittals when the evidence produced by a scent lineup appeared flawed or was

69 declared inadmissible (Ex parte Robbins 2016). Worse, some convictions have been overturned because

70 of questionable methods or from subsequent evidence indicating that a conviction was wrongful (Merjian

71 2009). The public image of scent identification procedures may have also suffered from reports that

72 scents of potential dissidents were stored by the East German Stasi for dogs to match with scents of

73 individuals whose scent could supposedly be found on flyers critical of the government (Makrakis 2008). 
75 The costs involved in maintaining scent lineup programs have led police administrators and

76 governments to question whether the technique is worth the expense and trouble, and in some

77 countries scent lineups are no longer being conducted despite the belief of police authorities and

78 prosecutors that the results are useful in investigations and prosecutions (e.g. The Netherlands).

79 Since the lineup method was initially developed and improved by handlers working mainly on

80 the basis of practical experience, only occasionally with input from scientists working in the

81 area, a general lack of standardization across countries and even within many countries as to

82 almost all details of the method is not surprising. Even when scientists were involved, their

83 suggestions were often ignored or only implemented in part. The authors therefore undertook a

84 comparative analysis of programs across their respective countries to determine how much

85 variation exists in lineup methodology between countries, and to survey the current status of

86 scent lineup programs. The authors make recommendations as to what should come next if this

87 method is to continue to be used and developed.

\section{MATERIALS AND METHODS}

90 After preliminary communications between researchers in several countries, an initial group of

91 those participating decided to collect data on specific aspects of the programs with which the

92 participants were familiar. The desire was to gather information on how scent lineups have

93 actually been conducted, not on what best practices should be, though many of us express

94 opinions on how various aspects of our country's programs could be improved. Comparing the

95 true reliability of scent lineups across countries, taking into account the differences in

96 procedures, would be difficult, particularly due to the logistic and organizational difficulties in

97 establishing that dogs of identical or similar proficiency are being deployed in each location. 
117 In the U.S., reported judicial cases provide detailed information on scent lineups and other scent 118

Such a study would also require that a large number of law enforcement agencies collaborate on an international comparative experiment, which the authors agree was logistically impossible.

The lead authors therefore established a list of questions in several stages of communications (made primarily by email) and collated the responses in order to describe variations and overlaps between programs, and thereby built a basis for discussing the present status of and the best future for the technique. In the survey, we limited comparisons to the methodological aspects of the lineups, without having comparative identification results as such. Methodological details were finally collected from 11 countries where the lineup identification is currently, or was in the past, applied by the law enforcement agencies, which are Belgium, the Czech Republic, Finland, France, Hungary, Lithuania, The Netherlands, Poland, Russia, Germany, and the U.S. Due to the federal structure of some countries, e.g., the U.S. and Germany, rules and practices may differ in different parts of these countries. In all countries except the U.S., responses were based on the direct knowledge of the respondents of the centralized or major canine identification facilities in their countries. As the lineup procedure is conducted according to unified regulations which are specific for each country and no variation of the method was expected within countries, only one leading unit responded, generally represented by a police expert with a good knowledge of the method applied in respective country. identification procedures actually introduced in criminal trials. Of the 50 states in the U.S., courts in only 17 states have produced decisions regarding a total of approximately 170 scent identification procedures, with the majority of procedures occurring in Texas and California. 
121 Although data on only this limited number of lineups could be gathered from judicial decisions,

122 the handlers involved testified that procedures they conducted, generally with minimal alteration

123 of methodology, had been used in thousands of cases (California v. Alonzo 2008, trainer had

124 produced scent identification evidence in between 1,700 and 1,800 investigations; Risher $v$.

125 Texas 2006, scent lineups conducted for over 30 law enforcement agencies; Robinson v. Texas

126 2006, dog had worked 760 human scent identification lineups; Pate v. Texas 2010, handler had

127 made "thousands" of scent identifications; U.S. v. McNiece 1983, handler had performed over

1281,000 scent lineups and claimed his dog had never been proven wrong, yet one of those cases

129 resulted in a wrongful conviction, as later established by DNA evidence, resulting in the State of

130 Texas awarding \$2 million damages (National Registry of Exonerations 2012)). Thus, judicial

131 opinions and orders describing scent lineup procedures collectively provide the most accurate

132 picture possible of scent lineups actually used in criminal prosecutions in the U.S.

134 As the responses were collected, the questions were divided into ten general categories, which 135 we believe is best displayed in a tabular format in ten tables, which are included in the Results 136 section below.

$138 \quad$ RESULTS

139 As expected, a general lack of international standardization of the lineup methods resulted in a great 140 heterogeneity of data and responses from different countries to particular questions formulated in the 141 questionnaire. Tables 1-10 summarize the responses provided by the participants to 29 questions. 
144 Scent samples are the essential items for the conduct of a lineup identification procedure. The properties

145 and methods of handling and storing of scent samples are crucial for the reliability of the identification.

146 Therefore, courts frequently question various details concerning how scent samples are obtained stored

147 and used in scent lineups (California v. Alonzo 2000).

\subsection{Materials that may hold scents}

150 Material used for collecting scent from objects or spots at crime scenes must fulfill several conditions. It 151 should be effective in absorbing scent, not react chemically with odor molecules and thereby alter the 152 odor, be easy to store over long periods without changes of odor quality or intensity, be easy to handle 153 (e.g. for multiplication of samples for testing, or be reusable for testing in the lineup), and not itself 154 contain an odor known to be aversive or attractive to dogs. In most countries, cotton pads or a mix of 155 cotton with synthetic fabrics, are used. In some countries the pads used for collecting scent samples are specially manufactured for this purpose and are sealed in sterile bags. Cotton pads are easily stored in

157 sealed sterile jars, can be multiplied either by cutting into smaller pieces or by putting additional pads in the jar to pick up odor by diffusion from pads previously placed in the jar.

In a number of countries the same material that is used to collect scent samples at crime scenes is also used to collect scents from the suspect and the decoys for use in the lineup. In The Netherlands, Finland, Belgium and in German federal state of Nordrhein-Westfalen, steel tubes are or have been used to collect scents from the suspect and the decoys for use in scent lineups. The idea of using such tubes is to enable a

164 sort of self-rewarding of the dog by retrieving the target tube, which is not fixed by an electromagnet, 165 whereas the decoy tubes are fixed.

\subsection{Collecting and handling of crime scene scent samples}

168 Collecting scent at a crime scene is the first step of osmological identification. In some countries, material evidence itself is collected. In other countries, scent samples are collected directly at the crime scene. 
Material evidence, or spots or objects from which scent samples are collected, are chosen by a forensic

171 technician on suppositions concerning where a perpetrator may have left scent. Thus, scent samples may

172 be taken from weapons or tools presumed to have been used by the perpetrator or places that must have

173 been touched, e.g. handles of doors, furniture, etc. In most cases, however, it is not known if a scent

174 sample collected at the crime scene contains any odor molecules, unless fingerprints are found on the

175 object from which scent samples were taken.

176

177 Both material evidence and scent samples used for forensic investigations are considered to be evidence 178 and therefore have to be precisely labeled, described, handled and safeguarded to avoid confusion with 179 other samples, contamination with other odors, or destruction. It is not always possible to know when the scent was left at the crime scene because it is not always possible to estimate exactly when the crime occurred. The retention of human odor on various surfaces and materials has been the subject of research that will need to be taken into consideration in developing standards for obtaining and storing scent samples (Prada et al. 2011; Hudson et al. 2009).

\subsection{Collecting and handling of suspect and decoy scents.}

186 Scent samples taken from the suspects and decoys are full scents that can be collected and stored at 187 recorded times and used within a specified period to ensure similar intensity. As with crime scene scent 188 samples, scent samples from suspects and decoys used for forensic investigations must be precisely 189 labeled, described, handled and safeguarded to avoid confusion with other samples and contamination

190 with other odors. Destruction of the suspect and decoy scent samples is seldom a problem because the 191 suspect and decoy sample donors generally remain available for repeated collection of the scent samples.

192 [Table 1 about here]

193 1.4. Time restrictions as to taking of scents of suspect and decoys and use in a lineup

194 Some countries emphasize that the timing of sampling decoys should be close to the timing of sampling a 195 suspect for scent. Some countries also have time limits as to the interval between when a sample is taken 
and when it can be used in a lineup. Primarily for organizational and logistic reasons it is usually not

197 possible to conduct lineup procedures immediately or shortly after taking scent samples, particularly those

198 obtained from crime scenes. Therefore, scent samples have to be stored until they are exposed to dogs.

199 Assuming odor molecules can diffuse from the scented material, even if stored in closed jars, or may

200 change their properties with time, a standardization of the storing time, especially setting a maximum

201 storage time, is preferable for making odors comparable in strength. Obviously, the time interval between

202 collection of a sample and using it in a lineup can be specified if such data are properly recorded. If decoy

203 samples are collected at a time that is significantly different from when a suspect's scent was collected,

204 this could represent a bias. Therefore, these two collection points should be as close as possible.

\subsection{Are stations in the lineup cleaned or replaced between trials or between dogs?}

207 Thoroughly cleaned sniffing rooms, isolated from any olfactory stimuli are generally required in

208 European programs, and stations are cleaned or replaced between dogs and sometimes between runs of

209 the same dog. Stations must generally be moved between runs of the same dog, and replaced entirely

210 between runs of different dogs.

212 Tops or edges of jars or containers with scent samples in the lineup may be touched by a dog's nose or

213 salivated upon, resulting in contamination or additional marking of the samples. This in turn may

214 influence the outcome of subsequent trials. Therefore, cleaning the work room and cleaning or replacing

215 the containers or scented items for each trial is widely recommended and often required. However, since

216 cleaning may create additional logistical problems, there may be a preference for replacing rather than

217 cleaning containers or stations for each trial. A station holds the jar or container with scent. Some

218 osmological laboratories also shift stations between consecutive trials. This, along with procedures for

219 cleaning or replacing jars or containers, can assure that the order of the stations as well as the order of the

220 containers is random. In other laboratories, the stations (which may be fixed to the floor) remain in place

221 and only the jar or container's position is randomized. 
224 Decoys are scents from individuals other than the suspect. Obtaining and proper use of decoy scents is 225 necessary to ensure unbiased indications can be made by dogs in a lineup. The purpose of using decoys in 226 the lineup is to demonstrate that the dogs discriminate scents of different humans and thus a matching of 227 scents can be accomplished. Using decoys increases the reliability and validity of identification.

228 Theoretically, the more decoys (and hence stations) in the lineup, the lower is the probability that 229 indications of the target sample are made by chance.

230 [Table 2 about here]

\subsection{Requirements on use of decoy scents in lineup}

232 Decoy scents are used in all countries surveyed, though the number of decoys varies considerably, 233 ranging from 4 up to 12 in a single trial. As a matter of practicality the number of decoys may be limited 234 in part on the size of the sniffing room which has to allow for enough distance between stations so as to 235 avoid confusion in assessing which station is actually being indicated by a dog. Care should also be taken 236 to avoid possible effects of scent plumes drifting over one or more neighboring stations, which is most 237 likely to happen when the stations are too close to each other and when there is any movement of air in 238 the room.

\subsection{Do decoy scents have to be taken from individuals who are similar to the suspect in sex, age,} 241 occupation, or other specified criteria?

242 Theoretically, the more the decoy scents are similar to that of the suspect with regard to gender, age, 243 occupation, and other criteria, the greater certainty that a dog has been able to distinguish an individually 244 unique, genetically determined and unchangeable component of the suspect's scent. Thus, using decoys 245 that are similar to the suspect increases the reliability of the identification of an individual as a 246 perpetrator. (See Schoon et al. 2009; Curran et al. 2007). Most countries require or prefer that decoy 247 scents be taken from individuals of the same gender and race or ethnicity, and often of similar age. Other 
criteria as to similarity of scents may include the profession of individuals sampled, where they live,

249 diseases they have, and medications they use.

\subsection{Can decoys be police officers?}

252 Often there is a practical problem in collecting decoy samples from a sufficient number of individuals, 253 though decoys cannot be police officers in the Czech Republic and only exceptionally in several other 254 countries. Since police officers are readily available as scent donors, there may be a tendency to collect 255 decoy samples from them. It cannot always be determined whether the police officers from whom decoy 256 scent samples have been taken were alien or familiar to the dogs used in a scent lineup. If the dogs are 257 familiar with scents of police officers used as decoys, the dogs may show a tendency to indicate a novel and/or distinctive scent of a perpetrator, independently of matching or not matching to the scent collected on the crime scene. This, in consequence, increases the likelihood of a false indication to an innocent suspect.

\subsection{Is there a requirement that all scents, including decoys, be novel (unfamiliar) to dogs during} training or testing (certification) stages, or in actual judicial trials?

264 In literature on scent lineups, concerns arise that dogs may memorize individual odor samples, even if 265 large numbers are used during training or in judicial trials. In cancer detecting dogs this may have 266 consequences in indicating by dogs the memorized pattern samples that were frequently used during 267 training, rather than generalization on a common odor of cancer markers (Elliker et al. 2014). In scent 268 lineups used forensically for human identification purposes, frequent use of the same samples as decoys 269 during the training stages, or during certification or in judicial trials, may result in a so-called pseudo270 match-to-sample (Hale 2017). Therefore, repetition of the use of samples from the same donor should be 271 avoided. Ideally, novel samples (donors) should be used for each trial. However, requirements as to the

272 scent samples used as decoys (Table 2) make the availability of novel decoy samples in numbers

273 sufficient for each procedure, including control trials, practically impossible and thus necessitate re-use of 
274 some samples. The responses to the question 2.4. indicate that the osmology experts are aware of the

275 problem of a systematic use of novel samples, even if there are no formal requirements but only

276 recommendations in this area, but re-use of samples is sometimes inevitable. Out of 11 countries

277 surveyed, in 7 countries only novel samples are used both in training, certification, and judicial trials, in 2

278 countries novel samples are combined with those re-used, in 1 country samples are frequently re-used.

279 From 1 country no information was available, probably due to a failure to distinguish between novel and 280 re-used scent samples.

\section{Control and disqualification trials}

283 The goal of control trials is to check (1) the disposition of the dog and its motivation for olfactory work 284 before further tests are performed, and (2) whether the scent of a suspect is, for any reason, "attractive" to 285 a dog, i.e. might be indicated regardless of actual matching or not matching to a reference or evidential scent. Control trials are those in which the target odor sample placed in the lineup and the sample given to

287 the dog to sniff at the starting point of the lineup (matching scents) are from the same person. For an

288 official trial, that person cannot have been involved in the forensic investigation and must be verified as

289 having never been present at the crime scene. Other scents in control trials are decoys, including

290 sometimes the scent of the suspect who will be subsequently tested in an official identification trial. Most

291 European countries surveyed employ control trials, generally just before a dog is used in an identification

292 trial. Such trials are rarely mentioned in U.S. cases and have never been judicially required. All European 293 countries surveyed except Belgium employ control trials before a dog is used in identification trials.

294 [Table 3 about here]

295 3.1. Number of disqualifying control trials

296 A dog can be used in official identification trials if it successfully completed control trials. The number of 297 control trials varies among respondent countries. In some countries, e.g. The Netherlands and Finland, 298 there is a fixed pattern of applying control trials, whereas in other countries, e.g. Poland, it is up to the 299 osmology expert to determine how many control trials should be conducted for qualification or 
disqualification of the dog before official identification trials. In some countries, e.g. the U.S., there is no

301 requirement for control trials, though some handlers conduct them. Generally, the number of control trials

302 has to strike a balance between several experimental needs: (1) checking of the dog's disposition for work

303 on a particular day, (2) not making the dog bored or tired because of the length of the activity, and (3)

304 leaving sufficient laboratory time for all trials to be conducted according to the identification protocol.

\subsection{Negative check (zero) trial requirement (as control or within identification trials)}

307 In a negative check or zero trial, there is no item in the lineup that matches the scent provided the dog 308 before it runs the lineup. Such a negative check might be one of the control trials or might be performed 309 in between the identification trials. Zero trials are considered to be more difficult for dogs than normal 310 control trials since they require a dog to refrain from indicating any sample, which can nevertheless 311 happen, for instance, if the dog is overly motivated to earn a reward. However, zero trials increase the 312 certainty that the dog will not indicate at any accidental station when there is no matching sample in the

313 lineup. Such trials are sometimes used in European practice, though there is no requirement in the Czech 314 Republic or Russia, and in The Netherlands and Finland such a control is only part of the certification 315 process. There is no requirement for such trials in the U.S., though such trials are sometimes performed.

\section{$317 \quad$ 3.3. Time intervals used between trials}

318 If matching consecutive pairs of scents occurs too quickly, short-term olfactory memory may cause the 319 dog to remember the previously sniffed scents and the dog may tend to duplicate a prior response and thus 320 fail to match subsequent scents correctly. Although separating stations by greater distances may help 321 slightly, rooms where trials are conducted are generally too small for this to be an ideal solution, so it is

322 best to build in a delay of several minutes between trials. The temporal gap between trials is also 323 important in (1) allowing time for the dog to receive award, (2) letting the dog understand that one trial is 324 over. 


\section{Experimental setup of the lineup identification}

327 Experimental setup may influence the outcome of the identification procedure and affect its reliability.

328 Unfortunately there is little experimental data comparing variations in such setups (Schoon 1996, 1997, 329 1998).

330 [Table 4 about here]

\section{$331 \quad$ 4.1. Number of stations in a trial}

332 Countries vary from 3 to 8 stations in a lineup, though circles of 10 and 12 stations are used in Poland and

333 Russia. Theoretically, the greater the number of stations in the lineup, and the fewer holding target

334 samples, the lower the probability that a correct hit will occur by chance alone. However, there are some

335 limitations as to the optimum number of stations in the lineup, such as available space in the sniffing 336 room for proper distances between stations. Another question concerns how many odors a dog may keep

337 in memory while working a lineup, so that the longer the lineup, the more odors the dog sniffs, potentially

338 resulting in the dog no longer holding the scent it is supposed to match in memory. Although the 339 question of how many odors a dog can be trained to identify has been a research subject (Williams \& 340 Johnston 2002, concluding dogs could be trained to identify at least 10 odors; Elliker et al. 2014, 12 odors

341 for at least one dog), the significance of canine working memory in lineup situations requires further

342 study. Also, dogs may omit some stations if there are too many of them, which introduces another 343 difficulty for statistical evaluation.

\subsection{Number of trials before an identification can be used as evidence in a criminal prosecution}

346 There are generally requirements for a number of identification trials before evidence can be used in a

347 prosecution, though this has not been true in the U.S. The number of official trials that may be conducted 348 may be limited by the number of scent samples available for a trial, particularly if procedures specify that 349 scent samples are to be exchanged between every trial and every dog. 
351 If dogs are rewarded during control trials, where the expert knows which target sample is correct, this

352 may cause problems in official trials where the expert does not know if there is an actual matching of a

353 suspect's scent to the evidential scent collected at the crime scene. This may lead to the situation where a

354 dog, frustrated as a result of not obtaining a reward, begins to make false alerts.

\subsection{Number of dogs used in an official identification}

357 The number of dogs for an official identification varies from 1 to 3-in very rare cases, 4- depending on

358 the country and local logistical capabilities. Some countries require that more than 1 dog reach the same 359 result before a scent lineup can be considered in a prosecution. Theoretically the more dogs used and the 360 more that indicate identically, the more statistically reliable is the lineup identification, even if the dogs

361 are not necessarily responding to the same set of odorants from an individual. However, when more dogs

362 are used in an official test, certain issues should be taken into account. First, such an increase in reliability

363 is only true if the dogs are working independently from each other, meaning that they are working on

364 physically different scent samples in the lineup to prevent any cues from an earlier dog indicating on a

365 particular sample. Second, dogs leave odor traces on the floor and in ambient air in the sniffing room,

366 which may interest or distract dogs used in subsequent tests (especially if males and females are used in

367 sequences) even though they were previously familiarized with these scents during training. Therefore, a

368 thorough removal of all odor traces in the sniffing room between each dog is recommended. Third,

369 although all dogs are formally certified, their performance in a lineup may differ. When more dogs are 370 used and there are discrepancies between their indications, it is difficult to justify simply accepting the 371 results of better dogs and ignoring the results of dogs found over time to be poorer performers.

\section{5. Alerting of dogs}


374 Since a dog's alert may be interpreted as matching scent found at a crime scene to scent of a suspect,

375 which practically means an identification of the perpetrator of a crime, the certainty that the dog has in

376 fact alerted faultlessly becomes crucial in the forensic and judicial use of scent identification procedures.

\section{7 [Table 5 about here]}

\section{$378 \quad$ 5.1. Who calls an alert?}

379 Alerts can be called by handlers in some countries, e.g., Hungary and the U.S., but must be called by 380 experimenters or technicians in others. Alerting by a dog should be overt and readable to anyone but some 381 dogs may have unique alerting behaviors readable only to their handlers, while other observers may have 382 doubts as to whether the dog is alerting or just hesitating. Therefore, the question of who calls alert may 383 be important for the outcome of the identification procedure. It is, in any case, essential that the person 384 calling the alert be unaware of the position of the suspect's odor since that may bias his judgement.

\subsection{Requirement that all stations be sniffed (even after correct alert)}

387 Some countries require that all stations be sniffed in the running of a lineup but others do not. During 388 training dogs are taught to sniff all stations in a lineup. However, when dogs become familiar with a 389 routine, they may develop a habit of not sniffing all stations systematically, and some are likely to stop 390 after indicating, particularly if rewarded.

\subsection{Is video-recording of official trials required or standard?}

393 Some courts require evidence that a lineup identification be made in accordance with state-of-the-art

394 techniques so as to eliminate doubt that the suspect's scent matches the scent found at the crime scene.

395 Some countries videotape procedures regularly, some only for more serious offenses, and some only

396 when evidence is being collected for specific use in a criminal trial. In some countries, defense lawyers

397 can ask to view videotapes of official identifications introduced at trial. Analysis of video-recordings may

398 provide additional information as to the sniffing and alerting styles of dogs and may be a useful material

399 for scientific studies. Clear alerts on videotapes may be particularly persuasive in judicial settings. 


\section{Degree of blindness}

402 Although scientific researchers place a premium on having as high a degree of blindness as possible,

403 practical implementation of the scent lineup procedure by police departments has resulted in considerable

404 variation on the blindness required in the conduct of scent lineups.

405 [Table 6 about here]

6.1. Degree of blindness required as to the placement of the target scent (i.e., whether the handler must be blind, whether an experimenter or technician within sight of the dog or the handler must be blind, and whether any other participant present during a lineup must be blind)

There are variations in the degree of blindness required for a scent lineup, though only in the Czech Republic, Hungary and partly in the U.S. may the handler know where the target sample is placed. Some countries (The Netherlands, Poland and Russia) require double-blindness, such that an experimenter or technician who knows where the target is placed cannot be within view of the handler or dog running the

413 lineup or anyone else present in the room where the dog is running the lineup. In the remaining countries 414 the questionnaires reported the degree of blindness which can be considered as single-blind, meaning that 415 only the dog handler is truly blind, while the presence of other persons (experimenter and/or assistant), 416 who are aware of the position of the target odor sample, is allowed within view of the handler and the 417 dog. Dogs have adapted behaviors to bring them close to humans over the course of their domestication, and 420 thus have considerable skill in reacting to commands and even subtle cues given by their human 421 caretakers (Miklosi et al. 2005; Lit et al. 2011). This ability is advantageous in many tasks of working 422 dogs. However, in some specific tasks, such as the lineup procedure, where the dog has to take a decision 423 on its own whether to perform or refrain from performing a specific task, a dog's looking for support or 424 cues from humans calls into question the integrity of the dog's responses to odor samples. Ultimately, in the lineup procedure, dogs have to match odors whose status as matching or not matching are unknown to 
either the osmology expert or the dog handler. However, during the training or control trials the matching

427 status of odors is known to both the expert supervising the trials and to the dog handler (no blindness), or

428 only to the expert but not to the handler (single-blind trials), or to neither of them (double-blind). No

429 blindness is useful during the initial phase of training when an immediate reward for obeying a command

430 to indicate the target sample is necessary. Single-blind trials are useful for control trials or for

431 maintenance training where the time interval between the dog's correct response and the reward must be

432 short. In such trials, the experimenter, who knows whether the dog's response was correct or false, may

433 give an acoustic or visual signal so that the dog can be rewarded.

In double-blind trials, neither the experimenter nor the dog handler nor any person within the range of the dog's senses is aware of the matching status of the tested odor samples. True double-blind trials are used during official testing of the suspect's odor sample for matching it to the sample collected at the crime scene. In such a trial no rewarding of a dog for indication of the target sample is appropriate since no one knows the matching status of the odor sample.

\subsection{Must an experimenter who is aware of the position of the target sample be totally isolated from} visual or auditory contact with the handler and the dog?

443 Dogs may respond to cues of individuals within their view other than their handlers (Buytendijk 1936).

444 Courts have occasionally recognized that cueing could come from persons, other than the handler, 445 watching a scent lineup who knew the location of a target (California v. White 2009). Sometimes the 446 distinction between double-blind and single-blind trials is vague, however. If, for instance, the technician 447 or the experimenter is totally isolated from any contact with the handler and the dog, and the handler is 448 unaware of the position of the target sample, it could be assumed that such tests are double-blind. 
Under a single-blind procedure there is a technical issue of how the signal confirming that the indication

453 of the dog was correct or false should be given so as to reward or not reward the dog properly. The signal

454 should be easy to operate from outside the sniffing room and audible or visible to the handler. Usually the

455 signal is given only after a correct indication by the dog and a lack of signal means that the indication was

456 false. Alternatively, another signal (e.g. another color of the lamp or another tone of an acoustic signal)

457 may be given to differentiate a correct indication from a false alert. After consistent use of a signal

458 system, a dog may become conditioned to particular signals and, in some cases, the acoustic signal itself

459 may then be perceived by the dog as a reward. The dog may also not sniff additional stations after this

460 point, as discussed above.

461

462

\section{Handling of dogs during trials}

463 The manner of handling dogs during trials and in their kennels, as well as during daily routines, may

464 influence the motivation to work and their effectiveness in performing tasks. It must be kept in mind that

465 dogs work a scent lineup for a reward, i.e., for a positive reinforcement. Dogs should enter the sniffing

466 room willingly in expectation of having an opportunity to fulfill their search and prey drives. Proper

467 handling of dogs may increase their motivation for sniffing, especially in the sniffing room.

468 [Table 7 about here]

469 7.1. Rewards that may be used for the dog, including treats, toys, etc.

470 Rewards appealing to dogs vary with their preferences. In contrast to drug or explosives detection dogs,

471 where the dogs should pay no attention to food, in the lineup procedure dogs are sometimes rewarded

472 with treats. This creates a risk of contaminating lineup material, particularly in U.S. scent lineups where

473 the majority of such lineups have been conducted using bloodhounds. For some dogs with a strong prey

474 drive, a toy to thrown to be retrieved may provide a greater motivation than a treat. However, throwing a

475 toy in the sniffing room may be inconvenient because a running dog could damage stations in the lineup

476 or hurt itself. Often there is a combination of a treat reward for a correct indication and a toy at the end of

477 the test to encourage the dog willingly to enter the sniffing room for the next test. The degree to which 
478 play is used should take into account the dog's age and whether it expended energy playing before the test

479 began.

\subsection{Timing of rewards}

482 Rewards are generally offered during the course of procedures, such as when there is a correct response, 483 often occurring after a clicker sound is made by an experimenter or technician to notify the handler to 484 provide a reward, but also sometimes at the end of work. Timing of rewards should follow precisely the right moment and not involve a long a delay such that the dog may not associate the reward with the correct reaction (Yamamoto et al. 2009; Hall and Wynne 2016; Minhinnick 2016). Although delayed rewarding is well known in practice, in order not to confuse the dogs most rewarding should directly follow a correct indication in the lineup. The sniffing of scent samples in the lineup takes only seconds and an imprecise rewarding technique may confuse the dog (see Browne et al. 2013, Browne 2014, finding that a delay in reinforcement as short as 1 second can impair learning).

\section{Dog characteristics and training}

493 The qualities of dogs in terms of their trainability, reliability, calmness, ability to focus on the task

494 (attentiveness), motivation, stamina, good health, and ease of handling are crucial for the lineup 495 procedure.

496 [Table 8 about here]

\section{$497 \quad$ 8.1. Breed preferences for scent lineups}

498 One of the most frequently asked questions concerns which breed is most suitable for working in the

499 lineup. There is no definite answer to this question since not only must breed characteristics be taken into 500 account but also individual predispositions of dogs. Some handlers argue that breeds known for their 501 excellent sense of smell (e.g. bloodhounds, particularly in the U.S.), though it may be doubted whether 502 dogs that work well outside (most judicially reported U.S. lineups were conducted outdoors, often near 503 crime scenes or where tracking led to a suspect) are actually the best candidates for scent lineups 
generally conducted inside. Work in the lineup is very different from tracking in terrain, and breeds

505 specialized in tracking can quickly become bored with the monotonous work of the lineup and thus

506 become useless. Breed preferences sometimes depend on country traditions and handlers' preferences as

507 well as on availability of particular breeds for police work. Although there is no consensus, German

508 shepherds and mixed shepherd breeds predominate across a number of countries.

\subsection{Age requirements for dogs performing scent lineups}

Dogs generally begin working after about a year of training, but there is considerable variation between countries as to the length of training programs. Dogs are sometimes required to retire at about 10 years of age. Lineup work requires focusing the dog on the task and the necessity of repeating the trial several times, which requires a strong motivation to earn a reward but to work without overly active and chaotic movement. Therefore, very young dogs are not appropriate, but rather dogs at least a year and a half old with a stable temperament and character are preferred. As the work in the lineup does not require a

517 special physical endurance, even older dogs may work well.

\subsection{Period of training before dogs can make an official identification or certification requirement}

520 Since results of canine identification in the lineup are often presented as evidence in courts, attention has

521 to be paid to qualification, sometimes involving a formal certification, of dogs used. The duration of the

522 training before a dog is considered ready for official identifications depends on the skills of the dog and

523 the handler as well as on the logistical and organizational issues. Retesting or recertification is common at 524 intervals or upon the perceived decline in a dog's abilities.

\section{Osmology expert and handler qualifications}

527 Qualification discussions sometimes consider only the requirements for the dog, but it is equally

528 important that persons involved in scent lineup procedures receive adequate training. An osmology expert

529 and dog handler should not only possess knowledge and skills on canine training and behavior, but 
530 preferably have at least basic qualifications in forensic techniques because improper handling and use of

531 scent samples as forensic material may affect the usefulness of the outcome of lineup procedures as

532 evidence from judicial point of view.

533 [Table 9 about here]

$534 \quad 9.1$. Qualification requirements for handlers

535 Handlers must generally be trained in specialized facilities before being able to produce official lineup

536 evidence. As with the other forensic procedures, experts in charge of conducting trials and authorized to

537 produce a final identification outcome, as well as the dog handlers who lead and reward the dogs, should

538 have proper and formally documented qualifications to perform their jobs.

\subsection{Can handlers have more than one dog?}

541 Handlers in most countries work with more than one dog. It is well known that between the dog and the

542 handler a special bond is created during training and deployment. It is also known that there must be a fit

543 in temperament and character between the dog and the handler. Also, to keep the dog in good physical

544 and mental condition, substantial time and effort is demanded of both the dog and the handler. Therefore,

545 as a best practice, a team of one dog paired with one handler is probably optimal. However, sometimes

546 for organizational reasons, a handler may work with two or more dogs.

547

548 9.3. Frequency and length of training sessions after teams begin performing scent lineups

549 Daily and weekly training sessions are designed to maintain proficiency. For maintaining a good working

550 performance, candidate dogs for lineup identifications require a well-designed initial training regimen,

551 while certified dogs require systematic sustaining training and exercising. The frequency and length of

552 training session may depend on the decision of the handler or on the official regulations for dogs

553 performing forensic tasks. 


\section{Measures undertaken to decrease judicial skepticism or public mistrust as to reliability and} validity of scent lineups in criminal prosecutions

557 Since identification of perpetrators by dogs is often presented as evidence in courts, it is obvious that 558 lawyers will inquire into the reliability of scent lineups, and how the evidential or diagnostic value of the 559 procedure can be quantified or characterized. Especially in cases of a positive identification by dogs, 560 where there is a minimal amount of other judicially recognized evidence, skepticism and mistrust has 561 been increasingly expressed by some judges.

562 [Table 10 about here]

10.1. Must the probability of a correct indication by chance be estimated, or is such an estimate standard?

565 When a dog has to match one of scent samples presented in a lineup, there is a certain probability of correct hits of the target sample occurring by chance alone. The lower this probability is the more valid

567 are the results obtained. The probability of correct hits by chance depends of the number of scents in the 568 lineup, the number of target samples, the number of trials, and the number of dogs. This probability also 569 depends on how correct indications are calculated. For instance, if a correct hit is considered as a choice 570 of one target out of $n$ samples sniffed in the lineup, the probability of correct hits by chance in one trial is $5711 / n$, but if a correct hit is considered as a single yes/no decision of the dog towards each sample sniffed in 572 the lineup, this probability is $50 \%$.

574 The following formula has been proposed by Koziol \& Sutowski (1998) and includes factorials for 575 calculation of the theoretical probability of correct hits by chance, taking into account the number of 576 samples in the lineup, the number of targets, of dogs and of trials:

$577 \quad \mathrm{P}=[\mathrm{k} !(\mathrm{n}-\mathrm{k}) ! / \mathrm{n} !]^{\operatorname{lm}}$

578 where:

$579 \mathrm{P}=$ probability of correct indication by chance in repeating trials several times with several dogs

$580 \mathrm{k}=$ number of target samples in the lineup

$581 \mathrm{n}=$ number of stands in the lineup 
$!=$ factorial (thus, if $\mathrm{n}=6,6 !=6 \times 5 \times 4 \times 3 \times 2 \times 1=720$ )

$5831=$ number of dogs used

$584 \mathrm{~m}=$ number of trials conducted

Courts are frequently interested in whether there is a significant likelihood that a dog's indication, even if

587 correct, was a "lucky guess." There are limitations to such a formula because consecutive scent lineup

588 trials are not fully independent from each other since the dogs may learn from one trial to another which

589 of the samples in the lineup are target or decoy samples. Also, if the same scent samples are used for more

590 than one dog, an earlier alert may have left cues on a sample that a later dog could respond to, meaning

591 that the lineups are not independent.

592

10.2. Have experimental studies been undertaken by independent scientific institutions to assess the validity and reliability of scent lineup identifications?

595 Lineup identifications are performed primarily by police officers who have specialized in canine training

596 and handling. However, in lineup procedures in general there has been a lack of scientific scrutiny,

597 without proper statistical analysis or any inquiry into the validity of procedures used by handlers.

598 Therefore, for forensic and judicial acceptance of the lineup procedure, assessment of a procedure should

599 involve independent scientific analysis with respected scientific tools. In some countries, such scientific

600 studies have been undertaken in independent scientific institutions and published in peer-reviewed

601 scientific journals (Schoon 1996, 1997, 1998; Jezierski et al 2008, 2010; Vyplelova et al. 2014), while in

602 others either no such studies have been conducted or any that were became parts of technical reports used

603 for vocational training, mostly lacking proper statistical proofs showing the significance of results. It

604 seems, however, that the results of scientific studies published in peer-reviewed international journals

605 were not sufficiently disseminated in law enforcement forces and taken into consideration by officers in

606 charge of osmology procedures, or even by lawyers in courts.

607

608 To answer questions by judges about the reliability of the lineup identifications, Schoon (1998) proposed

609 two parameters. The first was the diagnostic ratio of positive identification, defined as a ratio of percent 
of correct identifications in suspect $=$ perpetrator cases to percent of false identifications in suspect $\neq$

611 perpetrator cases. This ratio was experimentally estimated as high as 13.6, meaning that there could be

612 one false identification in every 13-14 positive identifications. A false identification may result in a false

613 accusation of the suspect, if the lineup identification is taken as the only evidence. The second parameter

614 proposed by Schoon (1998) was the diagnostic ratio of negative identification, defined as the ratio of

615 percent of correct non-identifications in suspect $\neq$ perpetrator cases to percent of misses in suspect $=$

616 perpetrator cases. The experimentally obtained diagnostic ratio of negative identification amounted to

617 2.6, which can be interpreted as one not identified perpetrator (in consequence falsely absolved by scent

618 lineup evidence) in every 2 to 3 negative identifications using a scent lineup.

619

620 However, significant individual differences in dogs' performances in operant conditioning during match-

621 to-sample trials were found by Jezierski et al. (2008). Additionally, the style and time of sniffing the scent

622 samples to be matched, and the number of stations sniffed or omitted were found to influence the

623 percentage of false alerts and false negative indications.

624

625 As an alternative to the traditional scent lineup consisting of several scent samples arranged in a line, a

626 different design using scented steel tubes and following an odd-even paradigm was examined by Schoon

627 (1997). Instead of comparing several samples in the lineup, dogs had to compare "odd," when the scent

628 presented to the dog at the starting point was different from the one placed on a platform, or "even," when

629 the scent presented at the starting point was identical with that on the platform. The other station on the

630 platform was always blank. If the trial was "odd" the dog was trained to go to the blank tube and respond

631 to this blank tube. It was found that, in comparison to the customary match-to-sample design, the new

632 design produced a comparable level of matching "even" scents but the level of non-matching "odd"

633 comparisons was substantially higher. This meant there were fewer false alerts, so it was concluded that

634 this new design would be more reliable. However, this proposed design has never been implemented in

635 police osmology praxis. 
637 More recently, it was shown by Marchal et al. (2016) that, due a rigorous procedure and continuous

638 training, a high sensitivity of $70 \%$ and $100 \%$ specificity, i.e. with no false alerts over 200 trials, could be

639 achieved. Interestingly, in this study, sensitivity increased with the number of trials. The authors believed

640 their results could convince law enforcement authorities not to withdraw the identification of humans on

641 the basis of individual scent as official forensic evidence. It has to be noted, however, that in contrast to

642 the claims of Marchal et al.(2016), a study by Jezierski et al. (2010) found that trained dogs, though easily

643 learning to perform operant conditioning responses in the scent lineup, displayed no significant

644 improvement of identification accuracy, both within particular training phases and during the working

645 phase, despite becoming more experienced as they worked.

646

647 In some countries studies have been conducted that were focused not specifically on demonstrating the 648 reliability of the scent lineup, but on properties of human individual odor that may be of importance for scent lineups as a forensic technique. For example, the results obtained by Vyplelova et al. (2014) suggest the existence of human odor fallout, whereby a human scent trace is left by humans even if they do not

651 touch an object. (See also Prada et al. 2011 regarding scent collection by placing a sorbent material in 652 contact with an item that has been in contact with an individual.) This finding, if confirmed, would be of 653 importance for extending of application of the scent lineup as a forensic technique. One recent paper 654 suggests that the effectiveness of scent lineups is compromised when certain training techniques are 655 employed with dogs, though the paper contained no experimental evidence that the conceptual framework 656 proposed would lead to better results in canine scent lineups (Hale 2017).

658 Generally, it is difficult to determine whether the canine level of performance makes this evidence 659 appropriately admissible in criminal prosecutions (Helton 2009, Ensminger 2016). Despite a number of 660 studies examining canine detection performance on a diverse array of tasks, it is difficult to make a 661 general comment about detection reliability. This is due to three problems listed by Helton (2009): (1), a 
662 lack of uniformity in reporting performance, (2), a lack of uniformity in testing conditions, and (3), a lack

663 of training information for dogs used in most studies. The results of the present survey generally confirm

664 a lack of uniformity of the lineup procedure among countries from which responses were obtained.

10.3. Has there been a decline or cessation of the use of scent lineups in police practice or judicial acceptance?

668 The use of scent lineups is either declining or has been terminated in a number of countries. In Germany, 669 scent lineup identification is carried out, if at all, by the police forces of the federal states. Due to the 670 federal structure of Germany with 16 federal states, the design of police procedures is a matter for the 671 states, with each state determining how the police service dog system is structured. For several years, the 672 lineup procedure is no longer in use and the method was used in the past in two federal states only. For 673 example, the federal state of Nordrhein-Westfalen had regulations between 1988 and 2011 as to the use of 674 the police in the scent lineup procedure. Also, from 1989 to 2012 the police forces in the federal state of 675 Baden-Wuerttemberg used a similar scent lineup procedure. In the past the scent lineup procedure was 676 used in the former GDR according to Methodological Guide on the use of scent differentiation in the fight 677 against crime, issued by the Ministry of Interior. Currently there are no special regulations for the use of 678 scent lineup. On the other hand, there are efforts to reintroduce the lineup procedure again. In Schleswig679 Holstein, for example, two dogs are specially trained and have already been used for criminal 680 investigations.

682 In The Netherlands, the lineup procedure, despite of being well based on high quality scientific studies, is 683 no longer used by police. The main reason was a lack of strict application of the prescribed methodology 684 and failure to demonstrate the required double-blind character of the procedure. This fact was revealed in 685 criminal cases which caused strong mistrust as to the reliability of the procedure and resulted in official 686 withdrawal of scent lineups from forensic practice. 
Scent lineups have been performed in Poland since 1962 (Bednarek 2008). The technique developed rapidly in police work during the period from 1997 to 2005, with dedicated laboratories, training of many dogs and staff, conduct of special workshops for osmology experts, and publishing of experimental

691 results and discussion articles in police and law journals. In 1998 there were 36 police osmological 692 laboratories deploying approximately 118 certified dogs and 936 identification procedures for courts were 693 performed. Due to the verification process and quality control, the number of osmological laboratories 694 decreased to 16 in 2005 , performing 1767 procedures. In 2015 the number of laboratories was reduced to 6956 , but doubts and controversies that emerged as to the reliability of the procedure, especially as evidence 696 for courts, resulted in a decline in the use of this procedure, although it is still performed (Dzierzanowskia 697 2016).

In the U.S., scent lineups as performed have been criticized as inadequate to produce judicial evidence almost since the beginning of their intense usage (Taslitz 1990). Even with the development of more advanced techniques in Europe, U.S. procedures remained primitive and well outside such advanced techniques, despite the occasional efforts of respected scientists and even FBI agents to portray them as reliable (Texas v. Dominguez 2011; California v. Alonzo 2008). No court (as of the end of 2018) has

704 issued a decision regarding a scent lineup that was actually performed from 2012 on. Cases on specific 705 handlers began to appear in the 1980s and 1990s, but most cases were issued between 2000 and 2011. 706 Due to a combination of (1) discrepancies between handler claims for the perfection of their dogs and 707 actual results, (2) overturned convictions, and (3) judicial skepticism, with many lawyers now calling 708 scent lineups a "junk science" (Thomas 2015), the future of scent lineups in the U.S. is in considerable 709 doubt. The leading legal critic of scent lineups acknowledged in 2013 that the adoption of European 710 techniques, if widely accepted in the scientific community, could lead to U.S. scent lineups becoming an 711 acceptable source of judicial evidence (Taslitz 2013).

\section{DISCUSSION}


714 Scent lineup procedures have been accepted by courts in the countries surveyed, though some of their

715 judicial systems no longer accept such evidence or have considerably reduced the instances where such

716 evidence is allowed in court. There is substantial overlap between most European programs on many

717 aspects of scent lineups, with divergence on certain other aspects. There is a greater degree of separation

718 of U.S. practice from European practice. The approaches in Europe generally follow a similar pattern,

719 though there are significant differences on specific aspects of how scent lineups are conducted. In the

720 U.S., handlers who perform scent lineups adapted their initial approaches from tracking work, only

721 occasionally and usually minimally incorporating concepts from the research literature. Nevertheless,

722 U.S. lineup procedures have sometimes been declared reliable by researchers who have studied scent

723 identification (e.g., Texas v. Dominguez 2011; California v. White 2013).

724

725 For all countries surveyed here except the U.S., questionnaires could be answered by describing standard

726 practices of specialized, and generally centralized, police units where scent lineups are conducted. Those

727 units establish standards for training dogs and personnel, as well as procedures by which data is produced

728 and evaluated before being provided to prosecutors for use in criminal trials. Magistrates generally have

729 the authority to determine whether the evidence proffered will be admitted in the determination of the

730 guilt or innocence of a defendant.

731

732 In the U.S., scent lineups as employed in criminal investigations and prosecutions are not conducted by a

733 centralized police unit but rather by individual handlers who are either employed by local police

734 departments or independent contractors who work on a regular or intermittent basis with a police

735 department or other law enforcement authority. Prosecutors then determine whether the scent lineup

736 results will be proffered as evidence during a trial, though judges may find various grounds for precluding

737 such evidence from being heard by a jury or considered by the judge acting as the trier of fact without a

738 jury. If the evidence is accepted by a court, the judge may issue an opinion or order in which he or she

739 discusses the nature of the scent lineup evidence produced at trial. 
741 Also, for all countries except the U.S., scent lineups are usually conducted in special isolated and

742 regularly cleaned rooms with standardized procedures. In the U.S., in contrast, the vast majority of

743 judicial cases where the location of a scent lineup was specified were outdoors in places like parking lots

744 (e.g., California v. Willis 2004) and open fields (though sometimes this is not specifically stated but rather

745 inferred from statements in an opinion about wind direction or weather conditions or the fact that joggers

746 might have been a distraction for the dog). When conducted indoors, the location was often a room in a

747 police station or a courtroom (e.g., Ramos v. Florida 1982). The reason lineups have so often been

748 conducted outdoors is that tracking dogs (particularly bloodhounds) were often used in scent lineups,

749 sometimes directly or soon after performing a tracking function (e.g., Brooks v. Colorado 1999;

750 California v. Demirdjian 2003). In 20 reported cases involving scent lineups, the dog or dogs used

751 performed an additional function in the investigation, generally tracking.

752

753 A further difference between the European countries surveyed here and the U.S. is that in Europe scent

754 lineups are usually conducted with scents on specialized pads or tubes, held in jars or clamped to

755 platforms that are frequently cleaned and in rooms that are also frequently cleaned. In the U.S., the item

756 sniffed is not always specified in judicial cases, but where this has been indicated, $26 \%$ were lineups of

757 persons, $17 \%$ were lineups of crime scene objects, and $57 \%$ were lineups using scent pads or other items

758 on which scent from a crime scene had been placed by rubbing or some other means. Lineups of persons

759 or objects have been reported in judicial cases even in the last 15 years. Where scent lineups use cotton

760 pads or other objects, it can seldom be said that the lineup was conducted in an environment that is free of

761 other olfactory stimuli, or in an area that had been, our could be, cleaned at all. Various U.S.

762 organizations, including SWGDOG (Scientific Working Group on Dog and Orthogonal detector

763 Guidelines), has published "recommended best practice general guidelines for training, certification, and

764 documentation pertaining to canines trained in conducting scent identification lineups." (SWGDOG SC 9:

765 Human Scent Dogs (Statement of Purpose). Although not specifically providing protocols for 
investigations, the training and certification recommendations contain elements of certain European

767 practices. (The SWGDOG organization has been replaced by the Dogs and Sensors Subcommittee of the

768 National Institute of Standards and Technology in the U.S. Department of Commerce, although the

769 documents issued by SWGDOG remain under that organization's imprint at present.) While such

770 guidelines have been referred to by handlers in courtroom testimony (U.S. v. Audelo-Marquez), those

771 guidelines have not been followed by working handlers who have testified in criminal trials. There may

772 be facilities within certain law enforcement organizations, such as the U.S. Federal Bureau of

773 Investigation (FBI), an agency perhaps closer to the centralized police authorities conducting scent

774 lineups in Europe, that could conduct scent lineups in a more sophisticated fashion than has been

775 demonstrated in U.S. case law, but evidence of such procedures is seldom available from U.S. case law.

776 In Iowa v. Frederiksen 2016, FBI agents used bloodhounds to match scents to attempt to determine

777 whether a suspects' scents could be found at locations associated with a crime. The scents of the suspects

778 were created using "a low airflow vacuum" and a "canine manager keeps the dog handlers "blind to the

779 case' to eliminate potential claims of bias. The case is notable for establishing that the FBI, as many other

780 agencies in the U.S., uses bloodhounds and scent transfer units (or something close to it) in scent work,

781 and that blindness of handlers is preferred, but it explains little about the agency's overall use of scent

782 identification dogs. One FBI official has testified on behalf of individual handlers even though the

783 techniques of those handlers would likely not satisfy SWGDOG guidelines (California v. Alonzo 2008).

784 Thus, SWGDOG and other guidelines remain theoretical and outside of the cases that have produced U.S.

785 judicial decisions and orders, and only the latter constitute the positive law of the U.S. on scent lineups.

787 The authors believe it is premature to suggest a list of best practices. Nevertheless, it is possible to

788 describe certain areas where police practices are similar, and certain areas of research consensus that may

789 indicate some starting points for an international effort and discussion towards best practices. There are

790 least two general approaches to materials that hold scent, i.e., (1) cotton (sometimes blended) and similar

791 materials and (2) steel tubes. There seems some value in continuing research with both types of scent 

videotaped.

materials. Scent samples in the lineup should only be used once for a dog since they may leave cues when they indicate. Objects holding scent in the lineup should be cleaned or replaced, and the position of target samples randomized, during official trials.

There is variation in both police practice and research traditions about the number of decoy scents in a lineup, but it might be possible to set a minimum number at 4 . Decoy scents are usually collected from individuals of the same race, gender, and age as the suspect, but additional similarities may be appropriate. Decoys should ideally not be police officers, but in any case should not be known to the dogs and should have no connection with the investigation or the investigating unit of a case. Scents presented together in a lineup should be collected as closely together in time as possible.

There should likely be disqualifying control trials, as well as zero trials, before an official trial, though this may also be an appropriate area for further research. There appears to be a consensus from both police and research practice as to how much a dog should work during a day or week. There is variation in the number of stations in both research and police practice and the area needs further research analysis. There should be a minimum number of trials before an identification can be introduced in a criminal trial. Many countries require more than one dog be used for an official identification, which again should receive further research attention.

Alerts should be visible to more than just the handler, so the handler should be able to describe a unique alert for a dog to an observer. To prevent any bias, the person calling the alert should not be aware of the position of the odor of the suspect in the lineup. There is no consensus as to whether all stations should be sniffed after a correct alert. This should receive additional attention as the absence of such a requirement affects the calculation of the statistical probability of a correct hit by chance. Official trials should be 
818 The authors believe that trials, except for the early stages of training, should be double-blind, i.e., blind as

819 to the handler as well as anyone whose presence may be perceived or sensed by the dog. Thus, an

820 experimenter who can call a correct alert in control trials should be separated from the lineup area in order

821 not to affect the handler's behavior, which might be a cue to the dog. The use of rewards is highly

822 variable and should be the subject of further research. When rewards are appropriately given, there is a

823 consensus that they should be given immediately after a correct indication through a conditioned

824 behavioral response.

825

826 The authors believe that the probability of correct indication by chance should always be calculated in

827 official trials, though we acknowledge that there is not a consensus in actual practice here. There should

828 be a greater connection between research groups around the world and between these groups and police

829 authorities that are implementing scent lineups. There has arisen both public and judicial suspicion

830 regarding lineups in many countries. This concern must be addressed if the technique is to continue in

831 forensic practice and judicial acceptance.

832

833 The authors acknowledge that the scent lineup may eventually be superseded by other forensic

834 approaches and specifically by the possibility that individual odors of humans may in time be identified

835 by techniques using gas chromatography/mass spectrometry. Cuzuel et al. (2017) noted that forensic

836 profiling of human odor could be useful in supporting information provided by dogs for courts, but in

837 time it may be that such chemical techniques would relegate scent identifications to a secondary function

838 in identifying perpetrators by their odors.

840 CONCLUSION

841 The scent lineup, as a forensic procedure, is in serious trouble in some countries, and is

842 experiencing a decline of usage in others. It has to be taken for granted that the scent lineup 
843 identification will not show 100\% accuracy all the time. However, experimental studies where 844 statistical significance was estimated show that the identification accuracy of the scent lineup

845 significantly surpasses results produced merely by chance. This argues that scent lineup

846 identification of perpetrators can at least produce corroborative evidence so that neither courts

847 nor police should totally reject use of the procedure. On the other hand it has been widely

848 accepted that a scent-lineup identification must not be taken as the sole or principal evidence

849 leading to prosecution and sentencing. In view of some controversies and doubt related to the

850 fact that no absolute accuracy of the lineup identification could be proven, there was and will be

851 a tendency to dismiss this method totally from forensic practice. Nevertheless, the authors

852 believe that this technique, conducted with procedures, developed over the nearly thirty years in

853 which it has been subjected to scientific investigation, can provide valid forensic data for

854 criminal investigations and can be corroborative of other evidence in prosecutions. The authors

855 also believe that specific country experiences and resources can lead to acceptable variations in

856 procedures. In order to have a future as a forensic technique capable of producing such data and

857 evidence, the authors also agree that greater international communication and collaboration

858 should continue to produce research regarding this technique, and that disseminating the results

859 of such research will increase the probability of judicial acceptance in all countries where

860 sophisticated programs can be developed.

861

862 ACKNOWLEDGMENTS

863 The authors wish to thank Orsolya Horvath, Olga Smolova, and Alexander Ambaryan for their 864 assistance in gathering data for this article. 
Note about order of authors: The project was conceived and planned by B.F., T.J., and J.E.; A.S.

867 provided data for The Netherlands, obtained the assistance of contributors for Belgium and

868 Finland, and contributed to the final drafting of the general sections of the article. Nine authors,

Z.B., D.C., M.G., I.H., P.K., F.L., E.R., K.S, and L.W., provided information on specific countries

and are listed alphabetically by last name, their affiliations indicating the countries for which they

871 were responsible.

872

873

\section{REFERENCES}

874 Bednarek, T., 2008. Osmological evidence, forensic and law aspects (in Polish). Wydawnictwo

875

876

877

878

879

880

881

882

883

884

885

886

887

888

889

890

891

892

893

894

895

896

897

898

899

900

901

902

903

904

Centralnego Laboratorium Kryminalistycznego KGP, Warsaw, Poland.

Brooks v. Colorado, 975 P.2d 1105 (Colo. Sup. Ct. 1999).

Browne, C.M., 2014. The effects of delayed positive reinforcement on learning in dogs. Ph.D. thesis, University of Waikato. https://researchcommons.waikato.ac.nz/handle/10289/9808.

Browne, C.M., Starkey, N.J., Foster, T.M., and McEwan, J.S., 2013. Delayed reinforcement-does it affect learning? J. Veterinary Behavior 8, e27-e28 (conference abstract).

Buchanek v. City of Victoria, No. V-08-08, 2009 WL 500564 (S.D. Texas 2009)

Buytendijk, F.J.J. (1936). The Mind of the Dog, pp. 99-100. Houghton Mifflin, Boston.

California v. Alonzo, 2008 WL 2248628 (Ct. App. 2008).

California v. Chavez, 2004 WL 1173075 (Ct. App. 2004).

California v. Demirdjian, GA043471, 2003 WL 1963204 (Los Angeles County Super. Ct. 2003).

California v. Jackson, 1 Cal.5 ${ }^{\text {th }}$ 269, 205 Cal.Rptr.3d 386, 376 P.3d 528 (Sup. Ct. 2016).

California v. White, 2009 Westlaw 3111677 (Ct. App. 2009).

California v. Willis, 9 Cal. Rptr.3d 235 (Ct. App. 2004).

Chen, M., Daly, M., Williams, N. Williams, S., Williams, C., and Williams, G. (2000). Non-invasive detection of hypoglycaemia using a novel, fully biocompatible and patient friendly alarm system. BMJ 321, 23-30. https://doi.org/10.1136/bmj.321.7276.1565. 
Curran, A.M., Ramirez, C.F., Schoon, A.E., and Furton, K.G. (2007). The frequency of occurrence and discriminatory power of compounds found in human scent across a population determined by SPMEGC/MS. J. Chromatography B 846, 86-97. doi.10.1016/j.jchromb.2006.08.039.

Cuzuel, V., Portas, F, Cognon, G., Rivals, I., Heulard, F., Thiebaut, D., and Vial, J. (2017). Sampling method development and optimization in view of human hand odor analysis by thermal desorption coupled with gas chromatography and mass spectrometry. Anal. \& Bional. Chem. 409(21), 5113-5124. doi.10.1007/s00216-017-0458-8.

Derda, W. (1983). Die Identifizierung von Spurenverursachern durch die Methode der Sicherung , Konservierung und Differenzierung von Geruchsspuren; Dissertation Hochschule der Deutschen Volkspolizei "Karl Liebknecht," Berlin.

Dzierżanowska, J. (2016). The methodology of osmological examination (in Polish). Metodyka ekspertyzy osmologicznej, Roczniki Nauk Prawnych 26(3), 25-37.

Elliker, K.R., Sommerville, B.A., Broom, D.M., Neal, D.E., Armstrong, S., and Williams, H.C. (2014). Key considerations for the experimental training and evaluation of cancer odour detection dogs: lessons learnt from a double-blind,controlled trial of prostate cancer detection. BMC Urology 14:22. https://doi.org/10.1186/1471-2490-14-22.

Ensminger, J. (2012). Judicial admissibility of scent lineup evidence, in: Ensminger, J. Police and Military Dogs: Criminal Detection, Forensic Evidence, and Judicial Admissibility. CRC Press, Taylor \& Francis, New York, pp. 89-96.

Ensminger, J. (2016). How U.S. courts deal with the "black box" of scent identification, in: Jezierski, T., Ensminger, J., and Papet, L.E. (Eds), Canine Olfaction Science and Law: Advances in Forensic Science, Medicine, Conservation, and Environmental Remediation. CRC Press, Taylor \& Francis, New York, pp. 199-213.

Ex parte Robbins, 478 S.W.3d 678 (Tx. Ct. Crim. App. 2016).

Gerritsen, R., and Haak, R. (2010). K9 Fraud! Fraudulent Handling of Police Search Dogs. Detselig Enterprises Ltd., Calgary, Canada.

Hale, E. (2017). Canine human-scent-matching: The limitations of systematic pseudo matching-tosample procedures. Forensic Sci. International 279, 177-186. DOI:10.1016/i.forsciint.2017.08.014

Hall, N.J., and Wynne, C.D.L. (2016). Canine olfactory learning and behavior, in: Jezierski, T., Ensminger, J, and Papet, L.E. (Eds.). Canine Olfaction Science and Law: Advances in Forensic Science, Medicine, Conservation, and Environmental Remediation. CRC Press, Taylor \& Francis, New York, pp. 125-139.

Helton, W.S. (2009). Overview of scent detection work: issues and opportunities, in: W.S. Helton (Ed) (2009). Canine Ergonomics: the Science of Working Dogs, CRC Press Boca Raton. pp. 83-97.

Horn, L., Range, F., and Huber, L. (2013). Dog's attention towards humans depends on their relationship, not only on social familiarity. Animal Cognition 16(3), 435-553. DOI:10.1007/s10071-0120584-9. 
Hudson, D.T., Curran, A.M., and Furton, K.G. (2009). The stability of collected human scent under various environmental conditions. J. Forensic Sciences 54(6), 1270-1277. DOI:10.1111/j.15564029.2009.01153.x.

lowa v. Frederiksen, 2016 WL 4051655 (la. Ct. App. 2016).

Jezierski, T., Walczak, M., and Górecka, A. (2008). Information-seeking behaviour of sniffer dogs during match-to-sample training in the scent lineup. Polish Psychol. Bull. 39(2), 71-80.

http://dx.doi.org/10.2478/v10059-008-0010-y.

Jezierski, A.Górecka-Bruzda, M.Walczak, A.Świergiel, M.Chruszczewski, and B.L.Pearson (2010). Operant conditioning of dogs (Canis familiaris) for identification of humans using scent lineup. Anim. Sci. Papers Rep. 28(10), 81-93.

Jezierski, T., Sobczyńska, M., Walczak, M., Górecka-Bruzda, A., Ensminger, J. (2012). Do trained dogs discriminate individual body odors of women better than those of men? J. Forensic Sci. 57(3), 647-652. DOI:10.1111/j.1556-4029.2011.02029.x.

Kaldenbach, J. (1998). K9 Scent Detection. Detselig Enterprises, Calgary.

Koziol, P., and Sutowski, G. (1998). Scent identification: chance or certainty? (in Polish). Problemy Kryminalistyki, 222, 37-39.

Kurahashi, T. and Menini, A. (1997). Mechanism of odorant adaptation in the olfactory receptor cell. Nature 385(6618), 725-729. DOI:10.1038/385725a0.

Lit, L., Schweitzer, J.B., and Oberbauer, A.M. (2011). Handler beliefs affect scent detection dog outcomes. Animal Cognition 14(3), 387-394. DOI.10.1007/s10071-010-0373-2

Makrakis, K. (2008). Seduced by Secrets: Inside the Stasi's Spy-Tech World, Cambridge University Press, Cambridge.

Marchal, S., Bregeras, O., Puaux, D., Gervais, R., and Ferry, B. (2016). Rigorous training of dogs leads to high accuracy in human scent matching-to-sample performance. PLoS ONE 11(2), e0146963. https://doi.org/10.1371/journal.pone.0146963.

Merjian, A.H. (2009). Anatomy of a wrongful conviction: State v. Dedge and what it tells us about our flawed criminal justice system. U. Penn. J. Law \& Social Change 13, 137-168.

Miklosi, A., Pongracz, P., Lakatos, G., Topal, J., and Csanyi, V. (2005). A comparative study of the use of visual communicative signals in interactions between dogs (Canis familiaris) and cats (Felis catus) and humans. J. Comparative Psychology 119(2) 179-186. DOI:10.1037/0735-7036.119.2.179

Minhinnick, S. (2016). Statistical reliability confounders and improvement in advanced training patterns, routines, targets, alerts, distractors, reinforcement, and other issues, in: .Jezierski, T., Ensminger, J. and Papet, L.E. (Eds.), Canine Olfaction Science and Law: Advances in Forensic Science, Medicine, Conservation, and Environmental Remediation. CRC Press, Taylor \& Francis, New York, pp. 199-213. 
1002

1003

1004

1005

1006

1007

1008

1009

1010

1011

1012

1013

1014

1015

1016

1017

1018

1019

1020

1021

1022

1023

1024

1025

1026

1027

1028

1029

1030

1031

1032

1033

1034

1035

1036

1037

1038

1039

1040

1041

1042

1043

1044

1045

1046

1047

1048

1049

National Registry of Exonerations (Wilton Dedge), University of Michigan Law School and Michigan State University College of Law, https://www.law.umich.edu/special/exoneration/Pages/casedetail.aspx?caseid=3167.

Pate v. Texas, 2010 WL 3341853 (Ct. App. 2010).

Prada, P.A., Curran, A.M., and Furton, K.G. (2011). The evaluation of human hand odor volatiles on various textiles: A comparison between contact and noncontact sampling methods. J. Forensic Sciences 56(4), 866-881. DOI:10.1111/j.1556-4029.2011.01762.x

Prada, P.A., Curran, A.M., and Furton, K.G. (2015). Human Scent Evidence, CRC Press, Taylor \& Francis, New York, pp. 88-89.

Ramos v. Florida, 496 So.2d 121 (Fla. Sup. Ct. 1986).

Risher v. Texas, 227 S.W.3d 133 (Ct. App. 2006).

Robinson v. Texas, 2006 WL 3438076 (Ct. App. 2006).

Schoon, G.A.A. (1996). Scent identification lineups by dogs (Canis familiaris): experimental design and forensic application. Appl. Anim. Behav. Sci. 49, 257-267. https://doi.org/10.1016/0168-1591(95)00656$\underline{7}$.

Schoon, G.A.A. (1997). Scent identifications by dogs (Canis familiaris): a new experimental design. Behaviour 134, 531-550.

Schoon, G.A.A. (1998). A first assessment of the reliability of an improved scent identification line-up. J. Forensic Sci. 43(1), 70-75.

Schoon, G.A.A., and De Bruin, J.C. (1994). The ability of dogs to recognize and cross-match human odors. Forensic Sci. Intern. 69, 111-118.

Schoon, G.A.A., Curran, A.M., and Furton, K.G. (2009). Odor Biometrics, in: Li, S.Z. and Jain, A. (Eds.), Encyclopedia of Biometrics. Springer: Boston.

SWGDOG SC 9: Human Scent Dogs (Scientific Working Group on Dog and Orthogonal detector Guidelines, https://swgdog.fiu.edu)

Taslitz, A.E. (1990). Does the cold nose know - the unscientific myth of the dog scent line-up. Hastings Law J. 42, 15-134.

Taslitz, A.E. (2013). The cold nose might actually know? Criminal Justice 28(2), 4-8, 55-57.

Texas v. Dominguez, 425 S.W.3d 411 (Ct. App. $1^{\text {st }}$ Dist.-Houston 2011).

Thomas, S. (2015). Addressing wrongful convictions: An examination of Texas's new junk science writ and other measures for protecting the innocent. Houston Law Rev. 52, 1037-1066. 
Vyplelova, P., Vocalek, V., Pinc, L., Pacakova, Z., Bartos, L., Santariova, M., and Capkova, Z. (2014).

Williams, M., and Johnston, J.M. (2002). Training and maintaining the performance of dogs (Canis

\section{Table 1. Collecting and handling of scent samples}

\begin{tabular}{|c|c|c|c|c|c|}
\hline Country & $\begin{array}{l}\text { 1.1. Materials } \\
\text { that may hold } \\
\text { scents of suspect } \\
\text { and decoys }\end{array}$ & $\begin{array}{l}\text { 1.2 Storage of } \\
\text { crime scene scent } \\
\text { samples }\end{array}$ & $\begin{array}{l}\text { 1.3. Time } \\
\text { restrictions as to } \\
\text { how long after } \\
\text { crime scent } \\
\text { lineup may be } \\
\text { conducted }\end{array}$ & $\begin{array}{l}\text { 1.4. Time } \\
\text { restrictions as to } \\
\text { taking of scents } \\
\text { of suspect and } \\
\text { decoys and use in } \\
\text { lineup }\end{array}$ & $\begin{array}{l}\text { 1.5. Are stations } \\
\text { in the lineup } \\
\text { cleaned or } \\
\text { replaced between } \\
\text { trials or for } \\
\text { consecutive } \\
\text { dogs? }\end{array}$ \\
\hline Belgium & $\begin{array}{l}\text { Stainless steel } \\
\text { tubes }\end{array}$ & $\begin{array}{l}\text { Material evidence } \\
\text { collected at crime } \\
\text { scent stored in } \\
\text { plastic bag }\end{array}$ & Up till 30 days & $\begin{array}{l}\text { Not prescribed, } \\
\text { but generally } 1 \text { to } \\
2 \text { days }\end{array}$ & $\begin{array}{l}\text { Steel tubes are } \\
\text { used only once in } \\
1 \text { lineup with } 1 \\
\text { dog }\end{array}$ \\
\hline Czech Republic & $\begin{array}{l}\text { Aratex }(76 \% \\
\text { cotton, } 21 \% \\
\text { rayon, 3\% } \\
\text { polyamide), but } \\
\text { another product is } \\
\text { being tested }\end{array}$ & $\begin{array}{l}\text { Material evidence } \\
\text { collected at crime } \\
\text { scent stored in } \\
\text { glass jar }\end{array}$ & $\begin{array}{l}\text { Between } 2 \text { days } \\
\text { and } 8 \text { months }\end{array}$ & $\begin{array}{l}\text { Between } 2 \text { days } \\
\text { and } 8 \text { months }\end{array}$ & $\begin{array}{l}\text { Jars may be } \\
\text { replaced between } \\
\text { dogs; this is up to } \\
\text { the handler during } \\
\text { training }\end{array}$ \\
\hline Finland & $\begin{array}{l}\text { Stainless steel } \\
\text { tubes; we were on } \\
\text { the way to start to } \\
\text { use Kings Cotton }\end{array}$ & $\begin{array}{l}\text { Material evidence } \\
\text { collected at crime } \\
\text { scent stored in } \\
\text { special plastic bag } \\
\text { for arson samples, } \\
\text { or glass jars, or } \\
\text { scent sample } \\
\text { taken with Kings } \\
\text { Cotton gauze } \\
\text { stored in glass jar, } \\
\text { all at room } \\
\text { temperature and } \\
\text { preferably dark }\end{array}$ & $\begin{array}{l}\text { No formal } \\
\text { limitations, } \\
\text { usually within 1- } \\
2 \text { year }\end{array}$ & $\begin{array}{l}\text { Not prescribed, } \\
\text { but generally } 1 \text { to } \\
2 \text { days }\end{array}$ & $\begin{array}{l}\text { Steel tubes are } \\
\text { used only once in } \\
1 \text { lineup with } 1 \\
\text { dog; we changed } \\
\text { to have tubes in } \\
\text { glass jars on } \\
\text { platform; jars } \\
\text { used only once }\end{array}$ \\
\hline France & $\begin{array}{l}\text { Kapp Péterné }{ }^{\circledR} \\
\text { (Hungary) cotton } \\
\text { squares (for body } \\
\text { and trace scents) }\end{array}$ & $\begin{array}{l}\text { Material evidence } \\
\text { collected at crime } \\
\text { scent stored in } \\
\text { glass jar }\end{array}$ & $\begin{array}{l}\text { No specified } \\
\text { limits but trace } \\
\text { scents often } \\
\text { collected within } \\
24 \text { hours of } \\
\text { lineups; most } \\
\end{array}$ & $\begin{array}{l}\text { No specified } \\
\text { limits but trace } \\
\text { scents often } \\
\text { collected within } \\
24 \text { hours of } \\
\text { lineups; most }\end{array}$ & $\begin{array}{l}\text { Jars are changed } \\
\text { randomly between } \\
\text { successive trials } \\
\text { in training, and } \\
\text { scents are } \\
\text { replaced between }\end{array}$ \\
\hline
\end{tabular}




\begin{tabular}{|c|c|c|c|c|c|}
\hline & & & $\begin{array}{l}\text { common storage } \\
\text { time between } 1 \\
\text { day and } 3 \text { months }\end{array}$ & $\begin{array}{l}\text { common storage } \\
\text { time between } 1 \\
\text { day and } 3 \text { months }\end{array}$ & $\begin{array}{l}\text { dogs; in official } \\
\text { trials, jars are } \\
\text { rearranged } \\
\text { between runs of } \\
\text { the same dog; } \\
\text { cotton squares in } \\
\text { jars are replaced } \\
\text { between trials } \\
\text { using different } \\
\text { dogs }\end{array}$ \\
\hline $\begin{array}{l}\text { Germany } \\
\text { Nordrhein- } \\
\text { Westfalen } \\
\text { Former German } \\
\text { Democratic } \\
\text { Republic }\end{array}$ & $\begin{array}{l}\text { Stainless steel } \\
\text { tubes } \\
\text {. } \\
\text { Cloth stored in } \\
\text { jars. }\end{array}$ & & & $\begin{array}{l}\text { Not specified, } \\
\text { preferably as soon } \\
\text { as possible } \\
24 \text { hours after the } \\
\text { scent is taken }\end{array}$ & $\begin{array}{l}\text { Replaced between } \\
\text { trials } \\
\text { For consecutive } \\
\text { dogs replaced } \\
\text { scent article } \\
\text { Replaced between } \\
\text { trials; if the dog } \\
\text { matches the target } \\
\text { scent five times } \\
\text { surely, the target } \\
\text { scent is } \\
\text { exchanged }\end{array}$ \\
\hline Hungary & $\begin{array}{l}\text { Special } 15 \times 20 \mathrm{~cm} \text {, } \\
\text { constant- } \\
\text { composition } \\
\text { textile made for } \\
\text { only this purpose. } \\
\text { It has to be made } \\
\text { of woolly and } \\
\text { loose material }\end{array}$ & $\begin{array}{l}\text { Material evidence } \\
\text { collected at crime } \\
\text { scent stored in } \\
\text { glass jar }\end{array}$ & $\begin{array}{l}24 \text { hours between } \\
\text { collection of scent } \\
\text { and use for an ID; } \\
\text { after } 3 \text { years scent } \\
\text { samples are } \\
\text { destroyed }\end{array}$ & $\begin{array}{l}24 \text { hours between } \\
\text { collection of scent } \\
\text { and use for an ID; } \\
\text { after } 3 \text { years scent } \\
\text { samples are } \\
\text { destroyed }\end{array}$ & $\begin{array}{l}\text { A dog performs } 5 \\
\text { trial; the glasses } \\
\text { used for the } \\
\text { lineup are not } \\
\text { exchanged or } \\
\text { cleaned, only their } \\
\text { position is } \\
\text { changed }\end{array}$ \\
\hline Lithuania & $\begin{array}{l}\text { Bleached flannel } \\
\text { cut to } 30 / 40 \mathrm{~cm} \\
\text { strips }\end{array}$ & $\begin{array}{l}\text { Material evidence } \\
\text { collected at crime } \\
\text { scent stored in } \\
\text { glass jar }\end{array}$ & $\begin{array}{l}\text { Scents can be } \\
\text { used } 24 \text { hours } \\
\text { after the } \\
\text { collection, but not } \\
\text { before; body } \\
\text { scents can be } \\
\text { stored for } 1 \text { year } \\
\text { only }\end{array}$ & $\begin{array}{l}\text { Scents can be } \\
\text { used } 24 \text { hours } \\
\text { after the } \\
\text { collection, but not } \\
\text { before; trace } \\
\text { scents can be kept } \\
\text { in the storage } \\
\text { room for } 5 \text { years } \\
\text { whereas body } \\
\text { scents can be } \\
\text { stored for } 1 \text { year } \\
\text { only }\end{array}$ & $\begin{array}{l}\text { Stations are } \\
\text { cleaned between } \\
\text { each trial and jars } \\
\text { containing scents } \\
\text { are replaced; } \\
\text { collected scented } \\
\text { material is } \\
\text { discarded and the } \\
\text { jars cleaned } \\
\text { before } \\
\text { sterilization }\end{array}$ \\
\hline Netherlands & $\begin{array}{l}\text { Stainless steel } \\
\text { tubes }\end{array}$ & $\begin{array}{l}\text { Material evidence } \\
\text { collected at crime } \\
\text { scent stored in } \\
\text { plastic bag, or } \\
\text { scent sample } \\
\text { taken with Kings } \\
\text { Cotton gauze } \\
\text { stored in glass jar, } \\
\text { all at room } \\
\text { temperature and } \\
\text { preferably dark }\end{array}$ & $\begin{array}{l}\text { No formal } \\
\text { limitations, } \\
\text { usually within } 1 \\
\text { year }\end{array}$ & $\begin{array}{l}\text { Not prescribed, } \\
\text { but generally } 1 \text { to } \\
2 \text { days }\end{array}$ & $\begin{array}{l}\text { Steel tubes are } \\
\text { used only once in } \\
1 \text { lineup with } 1 \\
\text { dog }\end{array}$ \\
\hline Poland & $\begin{array}{l}\text { Adsorbant swabs } \\
\text { consisting of } \\
\text { sterile cotton } \\
\text { sewed in sterile } \\
\text { gauze in closed }\end{array}$ & & & $\begin{array}{l}\text { Minimum } 24 \\
\text { hours unless } \\
\text { immediate ID is } \\
\text { necessary }\end{array}$ & $\begin{array}{l}\text { A separate set of } \\
\text { jars is used for } \\
\text { each dog; if a dog } \\
\text { has marked a jar } \\
\text { during a run, that }\end{array}$ \\
\hline
\end{tabular}




\begin{tabular}{|c|c|c|c|c|c|}
\hline & $\begin{array}{l}\text { bags } \\
\text { manufactured by } \\
\text { TZMO S.A. } \\
\text { Poland }\end{array}$ & & & & $\begin{array}{l}\text { jar is replaced } \\
\text { before the next } \\
\text { run of the same } \\
\text { dog }\end{array}$ \\
\hline Russia & $\begin{array}{l}\text { Cotton fleecy } \\
\text { fabric }(5 \times 3 \mathrm{~cm}\end{array}$ & $\begin{array}{l}\text { Sheets of cotton } \\
\text { fleece fabric with } \\
\text { scents of suspect } \\
\text { and decoys stored } \\
\text { in glass jars with } \\
\text { tight metal lids in } \\
\text { refrigerator }\end{array}$ & $\begin{array}{l}\text { No specified } \\
\text { limits. Lineup } \\
\text { procedures are } \\
\text { usually conducted } \\
\text { within } 24-72 \\
\text { hours after sample } \\
\text { collection, but } \\
\text { time interval } \\
\text { between sample } \\
\text { collection and } \\
\text { lineup can be } \\
\text { increased to } \\
\text { several weeks or } \\
\text { months }\end{array}$ & $\begin{array}{l}\text { Samples are } \\
\text { frozen } \\
\text { immediately in } \\
\text { chemically clean } \\
\text { dry ice, and can } \\
\text { be stored up to } 5 \\
\text { years in carbon } \\
\text { dioxide }\end{array}$ & $\begin{array}{l}\text { Each dog sniffs } \\
\text { clean jars with the } \\
\text { order of } \\
\text { presentation } \\
\text { changed. }\end{array}$ \\
\hline U.S. & $\begin{array}{l}\text { Scent lineups } \\
\text { have often used } \\
\text { objects collected } \\
\text { at the crime scene, } \\
\text { but also } \\
\text { footprints, } \\
\text { sometimes } \\
\text { transferred to } \\
\text { scent pads by } \\
\text { scent transfer } \\
\text { units (STU 100) }\end{array}$ & $\begin{array}{l}\text { No specified } \\
\text { requirements or } \\
\text { materials but } \\
\text { samples often } \\
\text { collected on gauze } \\
\text { pads with scent } \\
\text { transfer units } \\
\text { (STU 100) } \\
\text { (California v. } \\
\text { Alonzo 2008) }\end{array}$ & $\begin{array}{l}\text { No specified } \\
\text { requirements but } \\
\text { courts have } \\
\text { considered } \\
\text { storage and } \\
\text { contamination } \\
\text { issues, such as } \\
\text { where all decoy } \\
\text { scents were stored } \\
\text { in same duffel bag } \\
\text { in Ziploc bags } \\
\text { (Buchanek } v \text {. City } \\
\text { of Victoria 2009); } \\
\text { FBI uses glass } \\
\text { containers } \\
\text { (testimony of Dr. } \\
\text { Kenneth Furton in } \\
\text { Texas } v \text {. } \\
\text { Dominguez) }\end{array}$ & $\begin{array}{l}\text { Not prescribed } \\
\text { judicially and } \\
\text { seldom } \\
\text { mentioned, but } \\
\text { cases state testing } \\
\text { may follow } \\
\text { sampling in hours } \\
\text { up to } 3 \text { years in } \\
\text { one procedure }\end{array}$ & $\begin{array}{l}\text { There is no such } \\
\text { requirement and } \\
\text { some cases } \\
\text { indicate stations } \\
\text { were not changed } \\
\text { or moved between } \\
\text { successive runs or } \\
\text { different dogs }\end{array}$ \\
\hline
\end{tabular}

\begin{tabular}{|c|c|c|c|c|}
\hline Country & $\begin{array}{l}\text { 2.1. Requirements on } \\
\text { use of decoy scents in } \\
\text { lineup }\end{array}$ & $\begin{array}{l}\text { 2.2. Whether decoy scents } \\
\text { must be taken from } \\
\text { individuals similar to the } \\
\text { suspect in sex, age, } \\
\text { occupation, or other } \\
\text { specified criteria }\end{array}$ & $\begin{array}{l}\text { 2.3. Can } \\
\text { decoys be } \\
\text { police } \\
\text { officers? }\end{array}$ & $\begin{array}{l}\text { 2.4. Is there a requirement } \\
\text { that all scents, including } \\
\text { decoys, be novel (unfamiliar) } \\
\text { to dogs during training or } \\
\text { testing (certification) stages, } \\
\text { or in actual judicial trials? }\end{array}$ \\
\hline Belgium & $\begin{array}{l}\text { Scents from } 6 \text { decoys } \\
\text { are collected for lineup } \\
\text { of } 7 \text { scents, } 1 \text { being a } \\
\text { suspect); there are } 2 \\
\text { such lineups }\end{array}$ & $\begin{array}{l}\text { No identity requirement but } \\
\text { scents must be collected at } \\
\text { same place and time as } \\
\text { suspect's scent is collected }\end{array}$ & Yes & 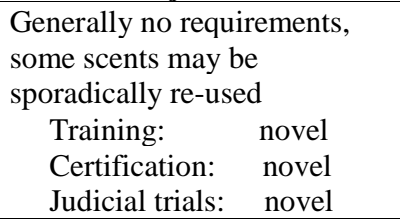 \\
\hline $\begin{array}{l}\text { Czech } \\
\text { Republic }\end{array}$ & $\begin{array}{l}\text { Practice is to use } 6 \\
\text { decoy scents and } 1 \\
\text { suspect (target) scent } \\
\text { per lineup }\end{array}$ & $\begin{array}{l}4,000 \text { body scents are stored } \\
\text { for maximum } 2 \text { years, } \\
\text { selected for specific lineups } \\
\text { based on the profile of the } \\
\text { suspect; decoy scents are } \\
\text { destroyed once used }\end{array}$ & No & $\begin{array}{l}\text { Training: } \quad \text { novel } \\
\text { Certification: novel } \\
\text { Judicial trials: } 1^{\text {st }} \text { dog novel } \\
2^{\text {nd }} \text { dog scents that } \\
\text { were used for the } 1^{\text {st }} \text { dog }\end{array}$ \\
\hline
\end{tabular}




\begin{tabular}{|c|c|c|c|c|}
\hline Finland & $\begin{array}{l}\text { Scents from } 6 \text { decoys } \\
\text { are collected for lineup } \\
\text { of } 7 \text { scents, } 1 \text { being a } \\
\text { suspect); there are } 2 \\
\text { such lineups }\end{array}$ & $\begin{array}{l}\text { No identity requirement but } \\
\text { scents must be collected at } \\
\text { same place and time as } \\
\text { suspect's scent is collected. If } \\
\text { suspect was female there } \\
\text { should also be female decoy }\end{array}$ & $\begin{array}{l}\text { Yes, some of } \\
\text { them, but not } \\
\text { from officers } \\
\text { involved or in } \\
\text { any way } \\
\text { connected } \\
\text { with } \\
\text { investigation }\end{array}$ & $\begin{array}{l}\text { Generally no requirements, } \\
\text { some scents may be } \\
\text { sporadically re-used } \\
\text { Training: novel } \\
\text { Certification: novel } \\
\text { Judicial trials: novel }\end{array}$ \\
\hline $\begin{array}{l}\text { Germany } \\
\text { Nordrhein- } \\
\text { Westfalen }\end{array}$ & $\begin{array}{l}\text { Practice is to use } 4 \\
\text { decoys in lineup of } 5 \\
\text { stations; scents can be } \\
\text { trace scents or body } \\
\text { scents } \\
1 \text { target scent, } 6 \text { decoys } \\
\text { taken in a similar way } \\
\text { on stainless steel tubes }\end{array}$ & $\begin{array}{l}\text { Decoy (distracting) scents are } \\
\text { collected from unrelated } \\
\text { persons identical to the sex, } \\
\text { age, and ethnicity of a suspect } \\
\text { Similar to the suspect as to } \\
\text { the sex and age, but this is not } \\
\text { specified in the method. }\end{array}$ & $\begin{array}{l}\text { Rarely, but } \\
\text { only in } \\
\text { training } \\
\text { phases } \\
\text { In practice } \\
\text { yes, but not } \\
\text { specified in } \\
\text { the method }\end{array}$ & $\begin{array}{l}\text { Training: } \quad \text { novel } \\
\text { Certification: novel } \\
\text { Judicial trials: } \\
\\
\\
\text { Training: } \quad \text { unknown } \\
\text { Certification: } \\
\text { Judicial trials: } \\
\text { unknown }\end{array}$ \\
\hline $\begin{array}{l}\text { Former } \\
\text { German } \\
\text { Democratic } \\
\text { Republic }\end{array}$ & $\begin{array}{l}1 \text { target scent, 6-8 } \\
\text { decoy scents }\end{array}$ & $\begin{array}{l}\text { Similar to the suspect as to } \\
\text { sex, age and profession (for } \\
\text { example butcher), but this is } \\
\text { not specified in the method }\end{array}$ & $\begin{array}{l}\text { In practice } \\
\text { sometimes, } \\
\text { but not } \\
\text { specified in } \\
\text { the method }\end{array}$ & $\begin{array}{ll}\text { Training: } & \text { novel / re-used } \\
\text { Certification: } & \text { unknown } \\
\text { Judicial trials: } & \text { unknown }\end{array}$ \\
\hline Hungary & $\begin{array}{l}\text { Time between } \\
\text { collecting scent from } \\
\text { decoys and the suspect } \\
\text { has to be as short as } \\
\text { possible; collecting } \\
\text { scent from person being } \\
\text { under the effect of } \\
\text { strong medicine or } \\
\text { drugs and from } \\
\text { menstruating women is } \\
\text { not allowed }\end{array}$ & $\begin{array}{l}\text { Only the sex of the decoy and } \\
\text { the suspect have to be } \\
\text { identical }\end{array}$ & $\begin{array}{l}\text { Yes, but not } \\
\text { from an } \\
\text { officer who } \\
\text { was at the } \\
\text { crime scene; } \\
\text { no official } \\
\text { rules }\end{array}$ & $\begin{array}{ll}\text { Training: } & \text { novel / re-used } \\
\text { Certification: } & \text { novel / re-used } \\
\text { Judicial trials: } & \text { novel / re-used }\end{array}$ \\
\hline Lithuania & $\begin{array}{l}9 \text { distractors are placed } \\
\text { on the circle and } 1 \\
\text { target }\end{array}$ & $\begin{array}{l}\text { Decoys are chosen in order to } \\
\text { be as similar as possible to the } \\
\text { target and the main factors are } \\
\text { sex and age }\end{array}$ & $\begin{array}{l}\text { Sometimes, if } \\
\text { the officers } \\
\text { have never } \\
\text { had contact } \\
\text { with the dogs } \\
\text { before }\end{array}$ & $\begin{array}{lc}\text { Training: } & \text { novel } \\
\text { Certification: } & \text { novel } \\
\text { Judicial trials: } & \text { novel }\end{array}$ \\
\hline Netherlands & $\begin{array}{l}\text { Scents from } 6 \text { decoys } \\
\text { are collected for lineup } \\
\text { of } 7 \text { scents, } 1 \text { being a } \\
\text { suspect); there are } 2 \\
\text { such lineups }\end{array}$ & $\begin{array}{l}\text { No identity requirement but } \\
\text { scents must be collected at } \\
\text { same place and time as } \\
\text { suspect's scent is collected }\end{array}$ & Yes & 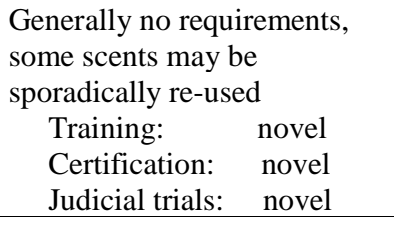 \\
\hline Poland & $\begin{array}{l}\text { Scents of } 10 \text { to } 20 \\
\text { decoys are collected; } \\
\text { separate scents are } \\
\text { collected for each dog } \\
\text { used }\end{array}$ & $\begin{array}{l}\text { Decoy scent samples are } \\
\text { collected from same sex and } \\
\text { ethnic group as suspect, } \\
\text { within } 5 \text { years of same age, in } \\
\text { a similar occupation, with } \\
\text { similar diseases and } \\
\text { medicines (if relevant) }\end{array}$ & $\begin{array}{l}\text { Yes, but not } \\
\text { from officers } \\
\text { involved or in } \\
\text { any way } \\
\text { connected } \\
\text { with } \\
\text { investigation }\end{array}$ & $\begin{array}{ll}\text { Training: } & \text { novel } \\
\text { Certification: } & \text { novel } \\
\text { Judicial trials: } & \text { novel }\end{array}$ \\
\hline Russia & $\begin{array}{l}13 \text { jars are prepared for } \\
\text { each trial; } 10 \text { for } \\
\text { decoys; more than } 1 \\
\text { suspect's scent can be } \\
\text { used; } 1 \text { of the last } 3 \text { jars } \\
\text { the dog sniffs contains a }\end{array}$ & $\begin{array}{l}\text { Some decoys should be of } \\
\text { same sex, age, and profession } \\
\text { as suspect, though not all } \\
\text { decoys must be so; forensic } \\
\text { investigators assure sampling }\end{array}$ & $\begin{array}{l}\text { Yes, if } \\
\text { unfamiliar to } \\
\text { dogs used in } \\
\text { lineups }\end{array}$ & $\begin{array}{ll}\text { Training: } & \text { novel / re-used } \\
\text { Certification: } & \text { novel } \\
\text { Judicial trials: } & \text { novel }\end{array}$ \\
\hline
\end{tabular}




\begin{tabular}{|c|c|c|c|c|}
\hline & $\begin{array}{l}\text { marker sample, the } \\
\text { scent the dog is } \\
\text { provided before } \\
\text { traversing the lineup }\end{array}$ & $\begin{array}{l}\text { of decoys and suspect are } \\
\text { close in time }\end{array}$ & & \\
\hline U.S. & $\begin{array}{l}\text { No standard practice } \\
\text { though of } 59 \text { cases } \\
\text { mentioning decoys, } 22 \\
\text { were used in lineups of } \\
\text { persons, } 11 \text { in lineups } \\
\text { with crime scene } \\
\text { objects, and } 26 \text { in } \\
\text { lineups using scent pads }\end{array}$ & $\begin{array}{l}\text { No judicial requirement; } 13 \\
\text { cases mention that the handler } \\
\text { used decoys of the same race } \\
\text { or ethnicity, and } 14 \text { mention } \\
\text { decoys of same gender; most } \\
\text { cases give no indication }\end{array}$ & $\begin{array}{l}\text { Decoys were } \\
\text { specified as } \\
\text { officers in } 10 \\
\text { cases, } \\
\text { including } \\
\text { police officers } \\
\text { in uniform in } \\
\text { lineups of } \\
\text { persons; many } \\
\text { other } \\
\text { procedures } \\
\text { probably used } \\
\text { scents of } \\
\text { police officers } \\
\text { as decoys }\end{array}$ & $\begin{array}{l}\text { Training: No requirement, and } \\
\text { decoys frequently re-used } \\
\text { Certification (generally tracking } \\
\text { dog certifications): sometimes } \\
\text { re-used } \\
\text { Judicial trials: No requirement, } \\
\text { decoys frequently re-used }\end{array}$ \\
\hline
\end{tabular}

1074

\section{Table 3. Control and disqualification trials}

\begin{tabular}{|c|c|c|c|}
\hline Country & $\begin{array}{l}\text { 3.1. Number of disqualifying } \\
\text { control trials }\end{array}$ & $\begin{array}{l}\text { 3.2. Negative check (zero) } \\
\text { trial requirement (as control } \\
\text { or within identification trials) }\end{array}$ & $\begin{array}{l}\text { 3.3. Time intervals } \\
\text { between trials }\end{array}$ \\
\hline Belgium & $\begin{array}{l}\text { Valid tracking certification and } \\
\text { additional valid scent lineup } \\
\text { module certification }\end{array}$ & No & $\begin{array}{l}3-4 \text { lineups can be } \\
\text { conducted per day, though } \\
\text { there is no required limit }\end{array}$ \\
\hline Czech Republic & $\begin{array}{l}2 \text { lineups (minimum) using crime } \\
\text { scene and suspect scents, but } \\
\text { additional control trials possible }\end{array}$ & $\begin{array}{l}\text { Prior to } 1 \text { April } 2018 \text {, such } \\
\text { trials were required after one or } \\
\text { two lineups performed } \\
\text { correctly; zero trials not } \\
\text { required after that date }\end{array}$ & $\begin{array}{l}\text { Quickly, perhaps } 1-2 \\
\text { minutes; dogs can work } 5 \\
-6 \text { runs per day, but } \\
\text { sometimes } 15-16\end{array}$ \\
\hline Finland & $\begin{array}{l}\text { Valid certification required, and } \\
\text { correct execution of } 2 \text { control } \\
\text { trials }\end{array}$ & $\begin{array}{l}\text { No requirement during official } \\
\text { lineups but used during } \\
\text { certification test }\end{array}$ & $\begin{array}{l}\text { Runs follow closely and } 4 \\
\text { runs can take } 2-4 \\
\text { minutes; between run } 2 \\
\text { and } 3 \text { team should have a } \\
\text { short break in next room, } \\
3-5 \text { min depending on } \\
\text { handler. } 3-4 \text { lineups can } \\
\text { be conducted per day, } \\
\text { though there is no required } \\
\text { limit }\end{array}$ \\
\hline France & $\begin{array}{l}3 \text { lineups with procedure similar } \\
\text { to training, } 15 \text { minutes before } \\
\text { official ID tests }\end{array}$ & $\begin{array}{l}\text { Zero trials used during training } \\
\text { stages, disqualifying trials, and } \\
\text { official ID lineups }\end{array}$ & $\begin{array}{l}\text { Minutes, no more than } 6- \\
8 \text { trials per day }\end{array}$ \\
\hline $\begin{array}{l}\text { Germany } \\
\text { Nordrhein- } \\
\text { Westfalen }\end{array}$ & $\begin{array}{l}\text { One control trial per dog to } \\
\text { exclude scent attractiveness }\end{array}$ & Not specified & $\begin{array}{l}\text { Usually consecutively on } \\
\text { the same day, no precise } \\
\text { time interval given. }\end{array}$ \\
\hline $\begin{array}{l}\text { Former German } \\
\text { Democratic } \\
\text { Republic }\end{array}$ & Not specified & Not specified & $\begin{array}{l}\text { Not specified but usually } \\
\text { consecutively on the same } \\
\text { day, no precise time } \\
\text { interval given; depends on } \\
\text { the dog; performance was } \\
\text { assessed by handler. }\end{array}$ \\
\hline Hungary & $\begin{array}{l}\text { Different (1-3) depending on the } \\
\text { department. }\end{array}$ & No requirement & $\begin{array}{l}\text { It depends on the dog. } \\
\text { Generally, there is no time } \\
\text { intervals between trials but }\end{array}$ \\
\hline
\end{tabular}




\begin{tabular}{|c|c|c|c|}
\hline & & & $\begin{array}{l}\text { if the dog needs rest, break } \\
\text { is allowed }\end{array}$ \\
\hline Lithuania & $\begin{array}{l}\text { Prior to each official test, all } \\
\text { dogs must complete two trials } \\
\text { correctly }\end{array}$ & $\begin{array}{l}\text { Negative check trials are } \\
\text { inserted during training; one } \\
\text { negative check every three } \\
\text { trials }\end{array}$ & $\begin{array}{l}\text { During the training period, } \\
\text { dogs run the circle several } \\
\text { times per day; there are } 15 \\
\text { minute intervals between } \\
\text { successive trials, once a } \\
\text { dog is certified, it is } \\
\text { trained once a day, } \\
\text { between } 2 \text { to } 5 \text { times a } \\
\text { week }\end{array}$ \\
\hline Netherlands & $\begin{array}{l}\text { Valid certification required, and } \\
\text { correct execution of } 2 \text { control } \\
\text { trials }\end{array}$ & $\begin{array}{l}\text { No requirement during official } \\
\text { lineups but used during } \\
\text { certification test }\end{array}$ & $\begin{array}{l}\text { Runs follow closely and } 4 \\
\text { runs can take } 2 \text { minutes; } 3 \\
-4 \text { lineups can be } \\
\text { conducted per day, though } \\
\text { there is no required limit }\end{array}$ \\
\hline Poland & $\begin{array}{l}3 \text { lineups (minimum), } 2 \text { with } \\
\text { sample randomly placed in lineup, } \\
\text { and } 1 \text { zero trial with no matching } \\
\text { sample }\end{array}$ & $\begin{array}{l}\text { Not conducted during official } \\
\text { trial sequences; one zero trial } \\
\text { out of } 3 \text { control trials sequence }\end{array}$ & $\begin{array}{l}\text { Lineups are separated only } \\
\text { by time needed to change } \\
\text { samples or positions; dog } \\
\text { can perform only } 1 \text { set of } \\
\text { tests per day }\end{array}$ \\
\hline Russia & $\begin{array}{l}\text { All dogs used must be tested } \\
\text { against decoys, with showing of } \\
\text { interest leading to disqualification }\end{array}$ & No requirement & $\begin{array}{l}4-5 \text { trials per dog per } \\
\text { day, but can be less of dog } \\
\text { appears not to be } \\
\text { motivated }\end{array}$ \\
\hline U.S. & $\begin{array}{l}\text { No statutory or judicial control- } \\
\text { trial requirement, though some } \\
\text { handlers run proofing trials }\end{array}$ & $\begin{array}{l}\text { No requirement, though } \\
\text { sometimes used by specific } \\
\text { handlers }\end{array}$ & $\begin{array}{l}\text { Generally runs follow } \\
\text { closely on one another, } \\
\text { though one case indicated } \\
\text { a } 10 \text {-minute gap between a } \\
\text { proofing procedure and a } \\
\text { lineup }\end{array}$ \\
\hline
\end{tabular}

1077

Table 4. Experimental setup of the lineup identification

\begin{tabular}{|c|c|c|c|}
\hline Country & $\begin{array}{l}\text { 4.1. Number of } \\
\text { stations in a trial }\end{array}$ & $\begin{array}{l}\text { 4.2. Number of trials before an } \\
\text { identification can be used as evidence in } \\
\text { a criminal prosecution }\end{array}$ & $\begin{array}{l}\text { 4.3. Number of dogs used in an } \\
\text { official identification }\end{array}$ \\
\hline Belgium & 7 & $\begin{array}{l}\text { No evidence in criminal prosecution - only } \\
\text { an indication }\end{array}$ & 1 \\
\hline $\begin{array}{l}\text { Czech } \\
\text { Republic }\end{array}$ & $3-7$ & 3 (by same dog) & $\begin{array}{l}\text { Depends on number of trace scents } \\
\text { collected at the crime scene; if only } \\
1 \text { scent, then only } 1 \mathrm{dog}\end{array}$ \\
\hline Finland & 7 & $\begin{array}{l}2 \text { control runs on } 7 \text { scents }(6 \text { decoys }+1 \\
\text { suspect), followed by } 2 \text { runs using crime } \\
\text { scene scent without control person A ( } 5 \\
\text { decoys }+1 \text { suspect })=4 \text { runs }\end{array}$ & $\begin{array}{l}1 \text { dog per lineup, no more than } 1 \\
\text { lineup is necessary }\end{array}$ \\
\hline France & 5 typically & $\begin{array}{l}2 \text { matching combinations (trace scent to } \\
\text { body scent and v.v.) are used with negative } \\
\text { check trials between tests ; then other dogs } \\
\text { perform similar sequences }\end{array}$ & $\begin{array}{l}\text { Minimum } 2 \text {, but } 7 \text { were used in a } \\
\text { case with a high level of crime } \\
\text { scene scents }\end{array}$ \\
\hline $\begin{array}{l}\text { Germany } \\
\text { Nordrhein- } \\
\text { Westfalem }\end{array}$ & 7 in lineup & $\begin{array}{l}6 \text { trials (including pre-testing); } \\
\text { Matching of suspect to crime scent is } \\
\text { recognized if } 3 \text { dogs independently of each } \\
\text { other match the tube touched by the } \\
\text { suspect. }\end{array}$ & 3 \\
\hline
\end{tabular}




\begin{tabular}{|c|c|c|c|}
\hline $\begin{array}{l}\text { Former } \\
\text { German } \\
\text { Democratic } \\
\text { Republic }\end{array}$ & $6-8$ in lineup & & $\begin{array}{l}\text { Not specified, but in practice at } \\
\text { least } 2\end{array}$ \\
\hline Hungary & 5 glass pots in a lineup & 5 trials & Minimum 2 dogs \\
\hline Lithuania & 10 in circle & $\begin{array}{l}2-3 \text { trials and the results must be } \\
\text { confirmed at least by another dog (so } 2 \\
\text { dogs minimum for a judicial ID) }\end{array}$ & At least 2 \\
\hline Netherlands & 7 & $\begin{array}{l}2 \text { control runs on } 7 \text { scents ( } 6 \text { decoys }+1 \\
\text { suspect), followed by } 2 \text { runs using crime } \\
\text { scene scent }=4 \text { runs }\end{array}$ & $\begin{array}{l}1 \text { dog per lineup, no more than } 1 \\
\text { lineup is necessary }\end{array}$ \\
\hline Poland & $\begin{array}{l}5 \text { minimum but } \\
\text { generally } 6 \text { for line; } 10 \\
\text { minimum for circle }\end{array}$ & $\begin{array}{l}3-5 \text { control trials, followed by official } \\
\text { trials (runs), which can vary depending on } \\
\text { number of dogs used, but } 3 \text { minimum trials } \\
\text { for ID to be declared; outcome of each dog } \\
\text { must be consistent if } 2 \text { dogs used }\end{array}$ & 2 dogs for an official lineup \\
\hline Russia & $\begin{array}{l}12 \text { in circle; lines not } \\
\text { used }\end{array}$ & $\begin{array}{l}3 \text { runs per dog with alert to suspect's scent } \\
\text { by all } 3 \text { dogs is considered sufficient for } \\
\text { proof of ID; if } 1 \text { of first } 3 \text { dogs does not } \\
\text { alert to suspect's scent, dog } 4 \text { provides } \\
\text { sufficient proof with an alert to the } \\
\text { suspect's scent on } 3 \text { runs }\end{array}$ & $\begin{array}{l}3 \text { dogs minimum (or } 4 \text { if } 1 \text { of first } 3 \\
\text { does not alert correctly) }\end{array}$ \\
\hline U.S. & $\begin{array}{l}\text { Highly variable; often } \\
\text { not specified, but in } 1 \\
\text { case there were only } 2 \\
\text { stations, } 1 \text { case had } 3,7 \\
\text { cases had } 4,12 \text { cases } \\
\text { had } 5,15 \text { cases had } 6 \text {, } \\
\text { and } 1 \text { case had } 7\end{array}$ & $\begin{array}{l}\text { Most judicial cases found a single run with } \\
\text { an alert sufficient for admission of } \\
\text { evidence; } 60 \% \text { of cases involved } 1 \text { dog, } \\
20 \% \text { involved } 2 \text { dogs, and } 30 \% \text { involved } 3 \\
\text { dogs }\end{array}$ & $\begin{array}{l}\text { No specified number, and dogs } \\
\text { could perform more than } 1 \\
\text { function (in } 20 \text { cases, dogs were } \\
\text { used for more than one function, } \\
\text { usually tracking in the initial part } \\
\text { of the investigation, then for a } \\
\text { scent lineup once a suspect was } \\
\text { apprehended) }\end{array}$ \\
\hline
\end{tabular}

\section{Table 5. Alerting of dogs}

\begin{tabular}{|c|c|c|c|}
\hline Country & 5.1. Who calls alert? & $\begin{array}{l}\text { 5.2. Requirement that all stations } \\
\text { be sniffed (even after correct alert) }\end{array}$ & $\begin{array}{l}\text { 5.3. Is video-recording of official } \\
\text { trials required or standard? }\end{array}$ \\
\hline Belgium & handler & no & No - handler makes written rapport \\
\hline Czech Republic & $\begin{array}{l}\text { Handler in prior } \\
\text { procedure, but now the } \\
\text { expert in the experiment }\end{array}$ & $\begin{array}{l}\text { Yes; target scent sometimes placed at } \\
\text { end of line so dog must sample all } \\
\text { stations to correctly alert }\end{array}$ & Only when ordered by judicial authority \\
\hline Finland & $\begin{array}{l}\text { Handler calls, and gets a } \\
\text { light signal when dog is } \\
\text { correct; we started to } \\
\text { change it. Handler was } \\
\text { sitting with his back to } \\
\text { line ups, no eye contact; } \\
\text { supervisor would call the } \\
\text { alert }\end{array}$ & No & $\begin{array}{l}\text { No; all lineups was video-recorded for } \\
\text { supervisor use }\end{array}$ \\
\hline France & Technician & $\begin{array}{l}\text { No, sufficient to sniff stations until } \\
\text { dog alerts }\end{array}$ & $\begin{array}{l}\text { With positive ID, lineup is repeated and } \\
\text { videotaped }\end{array}$ \\
\hline $\begin{array}{l}\text { Germany } \\
\text { Nordrhein- } \\
\text { Westfalem }\end{array}$ & Assistant & $\begin{array}{l}\text { No, but this is not specified in the } \\
\text { method. }\end{array}$ & Yes \\
\hline
\end{tabular}




\begin{tabular}{|c|c|c|c|}
\hline $\begin{array}{l}\text { Former German } \\
\text { Democratic } \\
\text { Republic }\end{array}$ & $\begin{array}{l}\text { Handler (dog's behavior } \\
\text { is "down") }\end{array}$ & $\begin{array}{l}\text { Once alerted, the position of target } \\
\text { scent must be swapped. }\end{array}$ & No \\
\hline Hungary & $\begin{array}{l}\text { Handler (generally, } \\
\text { though sometimes there } \\
\text { is a separate } \\
\text { experimenter) }\end{array}$ & Not an obligation & Only on request \\
\hline Netherlands & $\begin{array}{l}\text { Handler calls, and gets a } \\
\text { light signal when dog is } \\
\text { correct }\end{array}$ & No & Not usually \\
\hline Lithuania & $\begin{array}{l}\text { The judicial expert who } \\
\text { placed the target in the } \\
\text { circle }\end{array}$ & $\begin{array}{l}\text { When the target is placed far away } \\
\text { from the beginning of the circle it is } \\
\text { not absolutely required. However, } \\
\text { there is no strict requirement. } \\
\text { Sometimes the dog handler asks for } \\
\text { his dog to sniff all stations, } \\
\text { sometimes not. In general, all stations } \\
\text { are checked }\end{array}$ & No \\
\hline Poland & $\begin{array}{l}\text { Alerts are expected to be } \\
\text { clear to anyone; } \\
\text { experimenter indicates by } \\
\text { a light signal if alert was } \\
\text { correct }\end{array}$ & No (though required during training) & $\begin{array}{l}\text { Required if crime could result in } \\
\text { sentence greater than } 3 \text { years } \\
\text { imprisonment, or upon order of court or } \\
\text { prosecutor; generally conducted } \\
\text { anyway }\end{array}$ \\
\hline Russia & Experimenter & $\begin{array}{l}\text { Yes (because marker in last } 3 \\
\text { stations) }\end{array}$ & Yes, uniformly \\
\hline U.S. & Handler & $\begin{array}{l}\text { No judicial requirement, but } \\
\text { procedures of some handlers require } \\
\text { all stations be sniffed }\end{array}$ & $\begin{array}{l}\text { No judicial requirement but } \\
\text { occasionally done }\end{array}$ \\
\hline
\end{tabular}

Table 6. Degree of blindness

\begin{tabular}{|c|c|c|c|}
\hline Country & $\begin{array}{l}\text { 6.1. Degree of } \\
\text { blindness required as } \\
\text { to the placement of } \\
\text { the target scent }\end{array}$ & $\begin{array}{l}\text { 6.2. Must an experimenter who } \\
\text { is aware of the position of the } \\
\text { target sample be totally isolated } \\
\text { from any contact with the } \\
\text { handler and dog? }\end{array}$ & $\begin{array}{l}\text { 6.3. Means by which observers and } \\
\text { handlers communicate, including } \\
\text { visual or acoustic signals, a clicker, } \\
\text { etc. }\end{array}$ \\
\hline $\begin{array}{l}\text { Belgium } \\
\text { Czech Republic }\end{array}$ & $\begin{array}{l}\text { Single-blind } \\
\text { (technician present is } \\
\text { aware) } \\
\text { None }\end{array}$ & $\begin{array}{l}\text { no } \\
\text { Not relevant because handler is } \\
\text { not blind }\end{array}$ & $\begin{array}{l}\text { Verbal notification by technician } \\
\text { Not applicable (no observers) }\end{array}$ \\
\hline Finland & Double-blind & Yes & Visual (light) \\
\hline France & $\begin{array}{l}\text { Single-blind } \\
\text { (technician present is } \\
\text { aware, though required } \\
\text { to look in opposite } \\
\text { direction to handler) }\end{array}$ & $\begin{array}{l}\text { No (but technician is alien to the } \\
\text { dog) }\end{array}$ & $\begin{array}{l}\text { Verbal notification of handler by } \\
\text { technician }\end{array}$ \\
\hline $\begin{array}{l}\text { Germany } \\
\text { Nordrhein- } \\
\text { Westfalem }\end{array}$ & $\begin{array}{l}\text { Single-blind (handler } \\
\text { must be blind) }\end{array}$ & $\begin{array}{l}\text { No, but this is not specified in the } \\
\text { method }\end{array}$ & $\begin{array}{l}\text { Green or red light, but not specified } \\
\text { in the decree. } \\
\text { Not specified }\end{array}$ \\
\hline
\end{tabular}




\begin{tabular}{|c|c|c|c|}
\hline $\begin{array}{l}\text { Former German } \\
\text { Democratic } \\
\text { Republic }\end{array}$ & $\begin{array}{l}\text { Depended on } \\
\text { individual case, } \\
\text { sometimes double- } \\
\text { blind, sometimes } \\
\text { single-blind, } \\
\text { sometimes the handler } \\
\text { knew position, } \\
\text { especially if scent } \\
\text { sample was taken by } \\
\text { handler. }\end{array}$ & $\begin{array}{l}\text { No, but this is not specified in the } \\
\text { method }\end{array}$ & \\
\hline Hungary & $\begin{array}{l}\text { Suspect/lawyers may } \\
\text { observe the tests being } \\
\text { visually isolated from } \\
\text { the dog, the dog } \\
\text { handler and the } \\
\text { experimenter by a one- } \\
\text { way mirror. The } \\
\text { experimenter and the } \\
\text { dog handler know the } \\
\text { position of the target } \\
\text { scent in the lineup, } \\
\text { however, do not follow } \\
\text { the dog and do not give } \\
\text { any signals to the dog }\end{array}$ & No & $\begin{array}{l}\text { The experimenter and the dog } \\
\text { handler are allowed to communicate } \\
\text { directly (verbally). No } \\
\text { communication is allowed between } \\
\text { observers and the dog handler or the } \\
\text { experimenter }\end{array}$ \\
\hline Lithuania & $\begin{array}{l}\text { Single-blind (handler } \\
\text { never knows where the } \\
\text { target is placed in the } \\
\text { circle }\end{array}$ & $\begin{array}{l}\text { No (technician is present in the } \\
\text { room) }\end{array}$ & Visual and clicker \\
\hline Netherlands & Double-blind & Yes & Visual (light) \\
\hline Poland & $\begin{array}{l}\text { Double-blind (expert } \\
\text { observes through one- } \\
\text { way mirror) }\end{array}$ & Yes & $\begin{array}{l}\text { Visual (lamp), to tell handler to bring } \\
\text { dog into or exit from sniffing room, } \\
\text { another lamp signals that indication } \\
\text { was correct or incorrect (or that } \\
\text { experimenter deems dog refusing to } \\
\text { work) }\end{array}$ \\
\hline Russia & Double-blind & $\begin{array}{l}\text { Yes (observes through video } \\
\text { monitor) }\end{array}$ & Acoustic (clicker) \\
\hline U.S. & $\begin{array}{l}\text { Handler was stated to } \\
\text { be blind in } 13 \text { cases } \\
\text { and not to be blind in } \\
4 \text {; double-blindness } \\
\text { seldom mentioned }\end{array}$ & $\begin{array}{l}\text { Generally no such separation of } \\
\text { function in judicial cases though } \\
\text { double-blindness as to observers } \\
\text { mentioned in } 1 \text { case }\end{array}$ & $\begin{array}{l}\text { Judicially described procedures with } \\
\text { handler blindness sometimes indicate } \\
\text { a second officer verbally notified the } \\
\text { handler when the dog alerted } \\
\text { correctly }\end{array}$ \\
\hline
\end{tabular}

\begin{tabular}{|l|l|l|} 
Country & $\begin{array}{l}\text { 7.1. Rewards that may be used for the dog, in } \\
\text { control trials including treats, toys, etc. }\end{array}$ & 7.2. Timing of rewards \\
& \\
\hline
\end{tabular}




\begin{tabular}{|c|c|c|}
\hline Belgium & Retrieving tube after hearing choice is correct & $\begin{array}{l}\text { Immediately after correct indication (self- } \\
\text { rewarding of dogs by retrieving a target tube } \\
\text { released from the electromagnet in the lineup) }\end{array}$ \\
\hline Czech Republic & Petting, 1 treat for reward & After a hit or correct response \\
\hline Finland & $\begin{array}{l}\text { Retrieving tube when green light appears for } \\
\text { handler; we changed it to give food and after that } \\
\text { toy first click or verbal, depending on handler }\end{array}$ & $\begin{array}{l}\text { Immediately after correct indication (self- } \\
\text { rewarding of dogs by retrieving a target tube } \\
\text { released from the electromagnet in the lineup); } \\
\text { we changed this so that after correct } \\
\text { alert/indication dog remained at the right position } \\
\text { pointing or standing or laying down, handler went } \\
\text { to dog and gave reward he wanted to use to dog } \\
\text { (food, ball/toy, tube); we also changed to tubes in } \\
\text { glass jars on the line-up. }\end{array}$ \\
\hline France & $\begin{array}{l}10 \mathrm{~g} \mathrm{Knacki}{ }^{\circledR} \text { sausage upon correct response; ball } \\
\text { at end of trial, but varied depending on the } \\
\text { preferences of dogs }\end{array}$ & $\begin{array}{l}\text { After a correct alert and technician signals } \\
\text { handler; or at the end of a negative check (zero) } \\
\text { trial, when the dog returns to the handler }\end{array}$ \\
\hline $\begin{array}{l}\text { Germany } \\
\text { Nordrhein- } \\
\text { Westfalem }\end{array}$ & Depends on individual dog, mostly toys & Immediately after correct indication \\
\hline $\begin{array}{l}\text { Former German } \\
\text { Democratic } \\
\text { Republic }\end{array}$ & $\begin{array}{l}\text { Not specified, but in practice treats after each } \\
\text { correct indication }\end{array}$ & $\begin{array}{l}\text { Not specified, but in practice immediately after } \\
\text { each correct indication }\end{array}$ \\
\hline Hungary & Different rewards, praise, petting, food, toy & $\begin{array}{l}\text { After indicating of the target scent or after } \\
\text { refraining from a false alert and returning to the } \\
\text { handler }\end{array}$ \\
\hline Lithuania & A treat or a toy, depending on dog's preference & $\begin{array}{l}\text { Reward is given when a dog indicates the correct } \\
\text { station }\end{array}$ \\
\hline Netherlands & $\begin{array}{l}\text { Retrieving tube when green light appears for } \\
\text { handler }\end{array}$ & $\begin{array}{l}\text { Immediately after correct indication (self- } \\
\text { rewarding of dogs by retrieving a target tube } \\
\text { released from the electromagnet in the lineup) }\end{array}$ \\
\hline Poland & Food treats, toys after completion of a test & $\begin{array}{l}\text { Rewards can be given after a run, after a correct } \\
\text { response, or after returning to handler; after } \\
\text { completing an entire test, dogs are given a toy to } \\
\text { retrieve }\end{array}$ \\
\hline Russia & Food after experiment gives acoustic click signal & Seconds after acoustic signal given \\
\hline U.S. & $\begin{array}{l}\text { Nothing judicially specified, but handlers } \\
\text { regularly use treats, praise and petting }\end{array}$ & $\begin{array}{l}\text { Generally not indicated but assumed to be after a } \\
\text { trial is completed }\end{array}$ \\
\hline
\end{tabular}

\begin{tabular}{|c|c|c|c|}
\hline Country & $\begin{array}{l}\text { 8.1. Breed preferences } \\
\text { for scent lineups }\end{array}$ & $\begin{array}{l}\text { 8.2. Age requirements for dogs } \\
\text { performing scent lineups }\end{array}$ & $\begin{array}{l}\text { 8.3.Period of training before dogs } \\
\text { can make an official identification } \\
\text { or certification requirement }\end{array}$ \\
\hline Belgium & $\begin{array}{l}\text { Mainly German } \\
\text { Shepherd }\end{array}$ & $\begin{array}{l}\text { No requirement but dogs begin } \\
\text { training at about } 1 \text { year old }\end{array}$ & $\begin{array}{l}\text { Generally about } 1 \text { year for tracking, } \\
\text { training on scent lineups is optional } \\
\text { and begins after dogs are certified for } \\
\text { tracking }\end{array}$ \\
\hline Czech Republic & $\begin{array}{l}\text { Commonly crossbreds } \\
\text { of Malinois, German } \\
\text { shepherd, and Dutch } \\
\text { shepherd }\end{array}$ & $\begin{array}{l}\text { No requirement but dogs begin } \\
\text { training at about } 1 \text { year old and } \\
\text { train for a little less than } 1 \text { year }\end{array}$ & $\begin{array}{l}1 \text { year after dog is } 1 \text { year old } \\
\text { preceded by } 10 \text { weeks of basic } \\
\text { training } \\
\text { Generally about } 1 \text { year }\end{array}$ \\
\hline
\end{tabular}




\begin{tabular}{|c|c|c|c|}
\hline France & $\begin{array}{l}\text { German shepherd } \\
\text { Belgian Shepherd }\end{array}$ & $\begin{array}{l}\text { Dogs enter program at } 2.5 \text { years, } \\
\text { oldest working dog is } 9 \text { years }\end{array}$ & $\begin{array}{l}\text { Dogs must give no false alerts over } \\
200 \text { trials, followed by } 1.5-2 \text { years } \\
\text { training }\end{array}$ \\
\hline $\begin{array}{l}\text { Germany } \\
\text { Nordrhein- } \\
\text { Westfalem } \\
\text { Former German } \\
\text { Democratic } \\
\text { Republic }\end{array}$ & $\begin{array}{l}\text { German shepherd or } \\
\text { Belgian shepherd, but } \\
\text { not specified in the } \\
\text { method. } \\
\text { German shepherd }\end{array}$ & $\begin{array}{l}\text { Age over } 1.5 \text { years (according to } \\
\text { DERDA, 1983) }\end{array}$ & $\begin{array}{l}\text { Not specified, depends on the } \\
\text { individual dog's training } \\
\text { performance } \\
4 \text { phases ( } 240 \text { hours) of an intensive } \\
\text { training (according to DERDA, } \\
1983 \text { ) }\end{array}$ \\
\hline Hungary & $\begin{array}{l}\text { German and Belgian } \\
\text { shepherds or their mix. }\end{array}$ & $\begin{array}{l}\text { No requirement but a dog must be } \\
\text { able to fulfill its tasks, though } \\
\text { generally from } 1.5 \text { to } 9 \text { or } 10 \\
\text { years. }\end{array}$ & 6 months \\
\hline Lithuania & German shepherd & $\begin{array}{l}\text { From } 2-3 \text { years old when they } \\
\text { begin to about } 10 \text { years old }\end{array}$ & $\begin{array}{l}\text { Training lasts approximately } 1170 \\
\text { hours. }\end{array}$ \\
\hline Netherlands & $\begin{array}{l}\text { Commonly crossbreds } \\
\text { of Malinois, German } \\
\text { shepherd, and Dutch } \\
\text { shepherd }\end{array}$ & $\begin{array}{l}\text { No requirement but dogs begin } \\
\text { training at about } 1 \text { year old and } \\
\text { train for a little less than } 1 \text { year }\end{array}$ & Generally about 1 year \\
\hline Poland & $\begin{array}{l}\text { German shepherd and } \\
\text { Labrador retriever, but } \\
\text { also Rottweilers and } \\
\text { others, sometimes } \\
\text { reflecting handler } \\
\text { preferences }\end{array}$ & $\begin{array}{l}\text { Dogs qualified at } 1-2 \text { years, and } \\
\text { sometimes retired at } 10 \text { years }\end{array}$ & $\begin{array}{l}6 \text { months at Kynology Department of } \\
\text { Police Training Centre, but up to } 12 \\
\text { months of handler training with } \\
\text { handle }\end{array}$ \\
\hline Russia & Jackal-dog hybrids & $1.5-10$ years & $\begin{array}{l}\text { Basic training c. } 3 \text { months, match-to- } \\
\text { sample training c. } 2 \text { months, learning } \\
\text { scent lineups c. } 1 \text { month }\end{array}$ \\
\hline U.S. & $\begin{array}{l}\text { Bloodhounds used in } \\
\text { more than half of } \\
\text { published cases, though } \\
\text { German shepherds and } \\
\text { Labrador retrievers } \\
\text { occasionally used }\end{array}$ & $\begin{array}{l}\text { No age requirements have been } \\
\text { specified by courts; age of dogs } \\
\text { were occasionally given, ranging } \\
\text { from } 2 \text { years old to } 11 \text {, with an } \\
\text { average age of } 6 \text { years }\end{array}$ & $\begin{array}{l}\text { No requirement, but individual } \\
\text { handlers select dogs for training at } \\
\text { about } 1 \text { year; period of training } \\
\text { highly variable; training as a tracking } \\
\text { dog was sufficient for a dog to } \\
\text { participate in a scent lineup in a } \\
\text { number of judicial decisions }\end{array}$ \\
\hline
\end{tabular}

Table 9. Osmology expert and handler qualifications

\begin{tabular}{|l|l|l|l|} 
Country & $\begin{array}{l}\text { 9.1. Qualification requirements } \\
\text { for handlers }\end{array}$ & $\begin{array}{l}\text { 9.2. Can handlers have } \\
\text { more than one dog? }\end{array}$ & $\begin{array}{l}\text { 9.3. Frequency and length of } \\
\text { training sessions after teams begin } \\
\text { performing scent lineups }\end{array}$ \\
\hline Belgium & $\begin{array}{l}\text { Handler tested with dogs on } \\
\text { proficiency but also pass a } \\
\text { theoretical test } \\
\text { Handlers obtain a certification } \\
\text { with their dogs, which involved } \\
\text { annual retesting, though this has } \\
\text { ceased }\end{array}$ & $\begin{array}{l}\text { Usually only 1 dog } \\
\text { exceptional }\end{array}$ & $\begin{array}{l}\text { Usually 50 hours/month but this } \\
\text { includes training on tracking }\end{array}$ \\
\hline Finland & $\begin{array}{l}\text { Handlers tested as team members } \\
\text { with their dogs on proficiency, }\end{array}$ & $\begin{array}{l}\text { Handlers may have 2 } \\
\text { dogs, but dogs have }\end{array}$ & $\begin{array}{l}\text { Not specified, usually } 2-3 \text { scent IDs } \\
\text { per day, 2 + 2 days per week; dogs }\end{array}$ \\
\hline
\end{tabular}




\begin{tabular}{|c|c|c|c|}
\hline & $\begin{array}{l}\text { but also must pass a test on legal, } \\
\text { forensic, and scientific scent } \\
\text { matters; handlers should be police } \\
\text { officers }\end{array}$ & $\begin{array}{l}\text { only } 1 \text { handler; dogs } \\
\text { were living at handlers } \\
\text { home; if handler was a } \\
\text { long time out of work } \\
\text { (pregnancy + maternity } \\
\text { leave or sick leave) } \\
\text { another handler could } \\
\text { handle that dog }\end{array}$ & $\begin{array}{l}\text { were also trained for id-tracking and } \\
\text { id-scent search (articles and } \\
\text { locations) }\end{array}$ \\
\hline France & $\begin{array}{l}\text { Police officers undergo dog } \\
\text { handling training sessions of } 3 \\
\text { months, followed by a final exam } \\
\text { that allows them to join the } \\
\text { canine center in Ecully }\end{array}$ & $\begin{array}{l}\text { Handlers may have } 2 \\
\text { dogs, but dogs have } \\
\text { only } 1 \text { handler }\end{array}$ & $\begin{array}{l}6-8 \text { training trials per day, } 5 \text { days } \\
\text { per week }\end{array}$ \\
\hline $\begin{array}{l}\text { Germany } \\
\text { Nordrhein- } \\
\text { Westfalem }\end{array}$ & $\begin{array}{l}\text { Not specified, only dogs and } \\
\text { handlers from the Nordrhein- } \\
\text { Westfalen State police school for } \\
\text { police dog handlers }\end{array}$ & Yes, in practice 2 dogs. & $\begin{array}{l}\text { Not specified, depends on the } \\
\text { individual dog's training } \\
\text { performance; annual certification } \\
\text { required }\end{array}$ \\
\hline $\begin{array}{l}\text { Former German } \\
\text { Democratic } \\
\text { Republic }\end{array}$ & $\begin{array}{l}\text { Dogs had to be trained at the } \\
\text { special school of the Ministry of } \\
\text { the Interior for service dogs in } \\
\text { Pretzsch (Spezialschule des } \\
\text { Diensthundewesen) }\end{array}$ & $\begin{array}{l}\text { Not specified, but in } \\
\text { practice two dogs }\end{array}$ & Not specified \\
\hline Hungary & $\begin{array}{l}\text { The dog handlers and their dogs } \\
\text { have to complete a special course }\end{array}$ & Yes & Minimum 2 hours 3 times a week \\
\hline Lithuania & $\begin{array}{l}\text { Dog handler must pass a } \\
\text { certification exam every } 18 \\
\text { months }\end{array}$ & $\begin{array}{l}\text { Handlers may have } 1 \text { or } \\
2 \text { dogs }\end{array}$ & 1 hour, $2-5$ times a week \\
\hline Netherlands & $\begin{array}{l}\text { Handlers tested as team members } \\
\text { with their dogs on proficiency, } \\
\text { but also must pass a test on legal, } \\
\text { forensic, and scientific scent } \\
\text { matters }\end{array}$ & $\begin{array}{l}\text { Handlers may have } 2 \\
\text { dogs, but dogs have } \\
\text { only } 1 \text { handler }\end{array}$ & $\begin{array}{l}\text { Usually } 2-3 \text { scent IDs per day, } 4 \\
\text { days per week }\end{array}$ \\
\hline Poland & $\begin{array}{l}\text { Obligatory training for } \\
\text { osmological ID is conducted by } \\
\text { the Police Kynology Department } \\
\text { of the Police Training Centre, } \\
\text { which includes an exam involving } \\
\text { theoretical aspects; during } \\
\text { training, each participant trains } 2 \\
\text { dogs; other requirements for other } \\
\text { aspects of osmology work }\end{array}$ & $\begin{array}{l}\text { A handler trains } 2 \text { dogs, } \\
\text { but maximum is } 3\end{array}$ & $\begin{array}{l}1 \text { training session of 6- } 20 \text { trials per } \\
\text { day, } 5 \text { days per week }\end{array}$ \\
\hline Russia & $\begin{array}{l}\text { No specific certification but } \\
\text { handlers must undergo an } \\
\text { educational program in osmology }\end{array}$ & $\begin{array}{l}\text { Program has all } \\
\text { handlers working with } \\
\text { all dogs }\end{array}$ & $\begin{array}{l}\text { Daily training if possible with } 1-3 \\
\text { trials }\end{array}$ \\
\hline U.S. & $\begin{array}{l}\text { None judicially required and } \\
\text { many are self-taught; some have } \\
\text { military training in working with } \\
\text { dogs }\end{array}$ & $\begin{array}{l}\text { No limit, though many } \\
\text { have } 3 \text { or even more }\end{array}$ & $\begin{array}{l}\text { No specified requirement, highly } \\
\text { variable in cases, but some U.S.- } \\
\text { based police dog organizations } \\
\text { recommend } 4 \text { hours per week }\end{array}$ \\
\hline
\end{tabular}




\begin{tabular}{|c|c|c|c|}
\hline Country & $\begin{array}{l}\text { 10.1. Must the probability } \\
\text { of a correct indication by } \\
\text { chance be estimated, or } \\
\text { such an estimate } \\
\text { standard? }\end{array}$ & $\begin{array}{l}\text { 10.2. Have experimental } \\
\text { studies been undertaken } \\
\text { by independent scientific } \\
\text { institutions to assess } \\
\text { validity and reliability of } \\
\text { scent lineup } \\
\text { identifications? }\end{array}$ & $\begin{array}{l}\text { 10.3. Are scent lineup } \\
\text { identifications currently } \\
\text { performed by police as evidence } \\
\text { for courts (or specify periods } \\
\text { when such were performed)? }\end{array}$ \\
\hline Belgium & $\begin{array}{l}\text { Because of fixed practice, } \\
\text { probability is known }\end{array}$ & No & $\begin{array}{l}\text { Not as evidence but in early } \\
\text { investigation lineup results steer } \\
\text { the investigation }\end{array}$ \\
\hline Czech Republic & No & Yes & Yes \\
\hline Finland & Yes & Yes & Yes \\
\hline France & No & Yes & Yes \\
\hline $\begin{array}{l}\text { Germany } \\
\text { Nordrhein- } \\
\text { Westfalen }\end{array}$ & $\begin{array}{l}\text { The probability of correct } \\
\text { indication by chance, using } \\
\text { three trained dogs has been } \\
\text { calculated as } 1: 1.2 \text { million }\end{array}$ & $\begin{array}{l}\text { Yes, by Prof. Dr. Hans } \\
\text { Hilden, Universität - } \\
\text { Gesamthochschule } \\
\text { Paderborn. }\end{array}$ & $\begin{array}{l}\text { Currently no } \\
\text { 1988-2011 Nordrhein-Westfalen } \\
\text { 1989-2012 Baden-Württemberg }\end{array}$ \\
\hline $\begin{array}{l}\text { Former German } \\
\text { Democratic } \\
\text { Republic }\end{array}$ & No, but not specified & Not specified & \\
\hline Hungary & No & $\begin{array}{l}\text { Yes, but the police were not } \\
\text { involved and were not } \\
\text { advised of the results }\end{array}$ & Yes \\
\hline Lithuania & $\begin{array}{l}\text { No, assuming that the } \\
\text { probability of a single } \\
\text { correct hit by chance is } \\
1 / 10, \text { and scents are } \\
\text { replaced after each trial, of } \\
\text { each dog and hits must be } \\
\text { confirmed } 2 \text { to } 3 \text { times by } \\
\text { the same dog and by at least } \\
\text { another dog, the total } \\
\text { probability is deemed very } \\
\text { low. }\end{array}$ & No & Yes \\
\hline $\begin{array}{l}\text { Netherlands } \\
\text { Poland }\end{array}$ & $\begin{array}{l}\text { Yes } \\
\text { No, though under previous } \\
\text { procedures this was } \\
\text { calculated and published }\end{array}$ & $\begin{array}{l}\text { Yes } \\
\text { Yes }\end{array}$ & $\begin{array}{c}\text { No } \\
1962 \text { - currently }\end{array}$ \\
\hline Russia & $\begin{array}{l}\text { Because of fixed standard } \\
\text { practice, such probability is } \\
\text { known }\end{array}$ & Yes & Yes \\
\hline U.S. & $\begin{array}{l}\text { No, though one } 2011 \text { Texas } \\
\text { case criticized a handler for } \\
\text { not calculating a rate of } \\
\text { error }\end{array}$ & $\begin{array}{l}\text { Not as to procedures used } \\
\text { by police and contract } \\
\text { handlers; research has been } \\
\text { done by U.S. researchers on } \\
\text { identification issues }\end{array}$ & $\begin{array}{l}\text { No reported uses for } 8 \text { years but } \\
\text { some states have not judicially } \\
\text { precluded uses of scent lineups }\end{array}$ \\
\hline
\end{tabular}




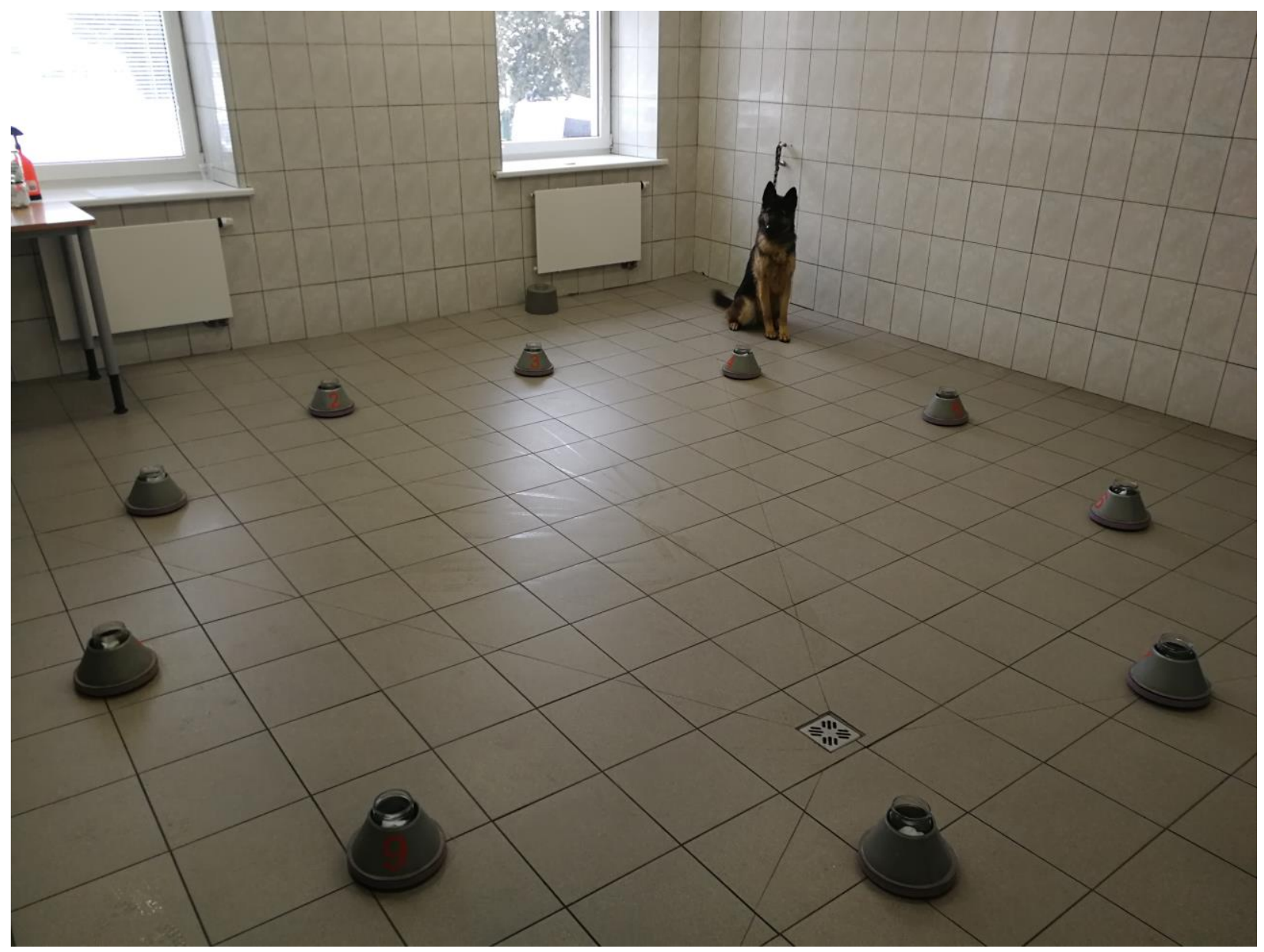


1126 Graphical abstract

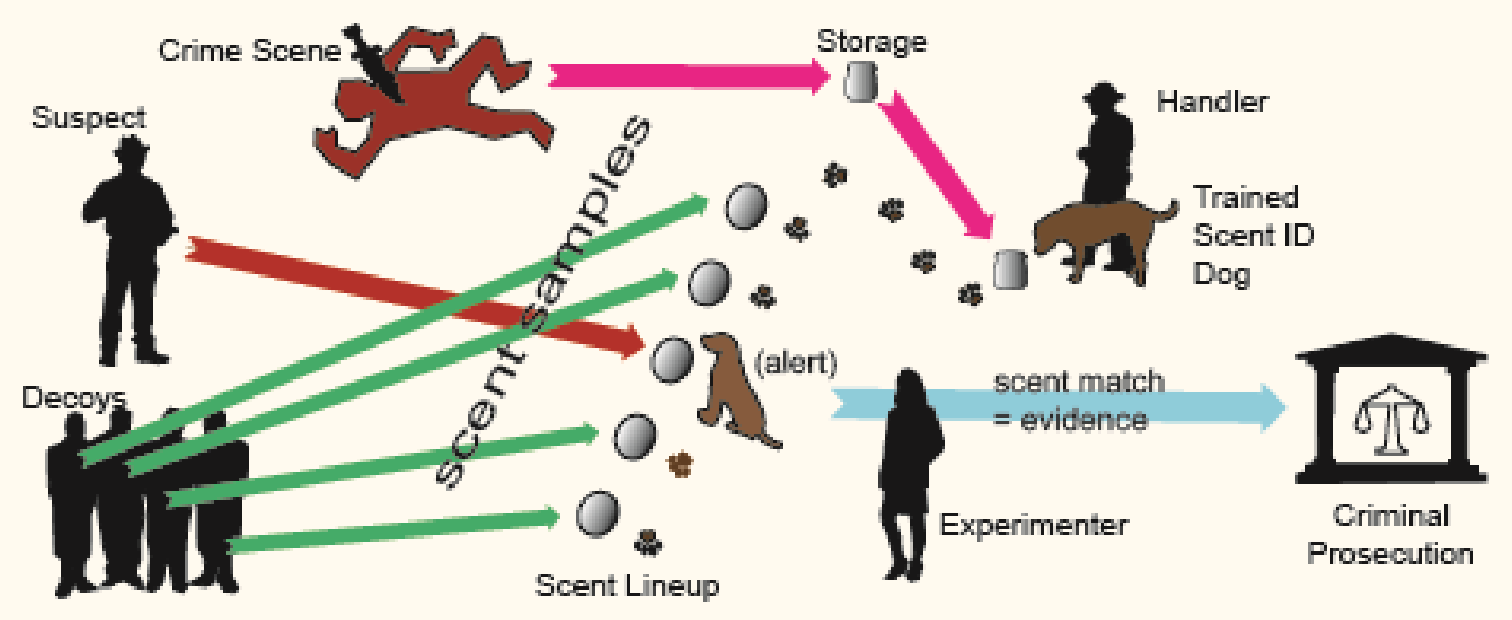

